\title{
MicroRNA EXPRESSION IN CANINE MAMMARY CANCER
}

\author{
A Dissertation \\ by \\ RENÉ MICHELLE BOGGS
}

\begin{abstract}
Submitted to the Office of Graduate Studies of
Texas A\&M University

in partial fulfillment of the requirements for the degree of

DOCTOR OF PHILOSOPHY
\end{abstract}

May 2008

Major Subject: Veterinary Microbiology 


\title{
MicroRNA EXPRESSION IN CANINE MAMMARY CANCER
}

\author{
A Dissertation \\ by \\ RENÉ MICHELLE BOGGS
}

\author{
Submitted to the Office of Graduate Studies of \\ Texas A\&M University \\ in partial fulfillment of the requirements for the degree of \\ DOCTOR OF PHILOSOPHY
}

\begin{abstract}
Approved by:
Chair of Committee, Keith Murphy

Committee Members, Ann Kier

Charles Long

Weston Porter

James Womack

Head of Department, Gerald Bratton
\end{abstract}

May 2008

Major Subject: Veterinary Microbiology 


\author{
ABSTRACT \\ MicroRNA Expression in Canine Mammary Cancer. \\ (May 2008) \\ René Michelle Boggs, B.S., Texas A\&M University \\ Chair of Advisory Committee: Dr. Keith Murphy
}

MicroRNAs (miRNAs) play a vital role in differentiation, proliferation and tumorigenesis by binding to messenger RNAs (mRNA) and inhibiting translation. To initiate an investigation into the identification of miRNAs in the domestic dog, an emerging model for human disease, a comparison of the human and canine genetic databases was conducted. The bioinformatics work revealed significant conservation of miRNA genes between the two species. Proof of principle experiments, including serial dilutions and sequencing, were performed to verify that primers made to amplify human mature miRNAs can be used to amplify canine miRNAs, providing that the mature sequences are conserved. TaqMan ${ }^{\circledR}$ Real-time RT-PCR, a sensitive and specific method, was used to isolate the first miRNA mature products from canine tissues. The expression levels of $m i R-17-3 p, m i R-17-5 p, m i R-18, m i R-19 a, m i R-19 b, m i R-20$, and $m i R-92$ were evaluated in five canine tissues (heart, lung, brain, kidney, and liver). Because miRNAs have been found to act as both tumor suppressors and oncogenes in several different cancers, expression patterns of ten miRNAs ( $m i R-15 a, m i R-16, m i R-17-5 p, m i R-21, m i R$ 29b, $m i R-125 b, m i R-145, m i R-155, m i R-181 b$, let-7f) known to be associated with 
human breast cancer were compared between malignant canine mammary tumors $(n=6)$ and normal canine mammary tissue $(\mathrm{n}=10)$. Resulting data revealed $m i R-29 b$ and $m i R-21$ to have a statistically significant $(\mathrm{p}<0.05)$ up-regulation in cancerous samples. Overall expression patterns showed nine of the ten miRNAs follow the same pattern of expression in the domestic dog as the human, while the miR-145 expression does not show a difference between the normal and cancerous samples. 


\section{DEDICATION}

To Mr. Firgens, Mrs. Dooley, Mr. Tobias, and Dr. Durham, my secondary science and math teachers who not only encouraged but inspired while consistently pushing me to be a better student and a better person 


\section{ACKNOWLEDGEMENTS}

I would like to thank my committee chair, Dr. Keith Murphy, and my committee members, Dr. Weston Porter, Dr. Charles Long, Dr. Ann Kier, and Dr. James Womack, for their guidance and support throughout the course of my graduate career. I look forward to our future collaborations. And thanks to Drs. Charles Scanlan and Tawfik Omran for giving me my start in the Veterinary Microbiology Laboratory.

Thanks also go to my friends and colleagues at Texas A\&M University. I would like to recognize the Canine Genetics Laboratory and the entire Department of Veterinary Pathobiology, especially the administrative staff who kept my records straight and a business permit handy. Thanks to Patsy Story, Ali Wilkerson, Drs. Stephanie Herbst, Jan Janecka, and Rick Metz and soon-to-be Drs. Christine New, Jacquelyn Wahl, Elizabeth Wellberg, and Brian Laffin who kept me laughing and smiling even when experiments were failing. And to my "partner-in-crime" Jessica Moody, you are a mentor, editor and friend. This project and my maintained sanity could not have happened without you. A special thanks to Drs. Zachary Wright and Mark Stickney who collaborated on the mammary cancer project, and to the Kier Lab for the use of the real time machine for the initial experiments. I want to extend my gratitude to the Canine Health Foundation which provided partial funding for this project.

Finally, thanks to my parents, Richard and Velma Sauer, and my husband, Captain Nicholas Boggs. You have always believed in me, been there for me, encouraged me, and reminded me of what is really important: family and love. 


\section{NOMENCLATURE}

\begin{tabular}{|c|c|}
\hline 3' UTR & 3' untranslated region \\
\hline AIB1 & Amplified in Breast Cancer 1 \\
\hline $\mathrm{C}_{\mathrm{T}}$ & critical threshold \\
\hline dsRNA & double stranded RNA \\
\hline ER & estrogen receptor \\
\hline HOXD10 & homeobox D10 \\
\hline IGF-I/II & insulin-like growth factor I/II \\
\hline IMC & inflammatory mammary carcinoma \\
\hline $\operatorname{miR}$ & microRNA \\
\hline miRNA & microRNA \\
\hline mRNA & messenger RNA \\
\hline $\mathrm{OHE}$ & ovariohystorectomy \\
\hline PR & progesterone receptor \\
\hline pri-miRNA & primary microRNA \\
\hline pre-miRNA & precursor microRNA \\
\hline qRT-PCR & $\begin{array}{l}\text { quantitative real time reverse transcription polymerase chain } \\
\text { reaction }\end{array}$ \\
\hline $\mathrm{R}^{2}$ & correlation value \\
\hline RISC & RNA Induced Silencing Complex \\
\hline RH & radiation hybrid \\
\hline
\end{tabular}


RNAi

RNA

shRNA

siRNA

TCF8

TPM1
RNA interference

ribonucleic acid

short hairpin RNA

short interfering RNA

transcription factor eight

tropomyosin one 


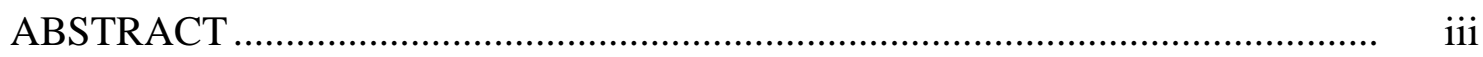

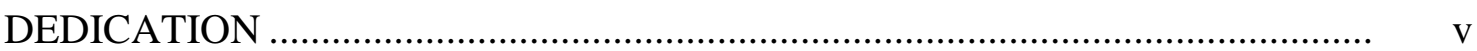

ACKNOWLEDGEMENTS ...................................................................... vi

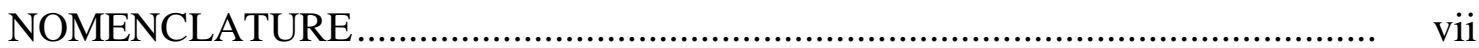

TABLE OF CONTENTS ……..................................................................... ix

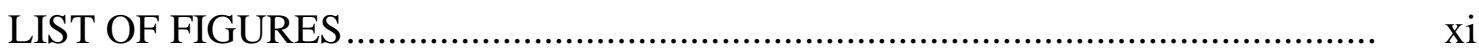

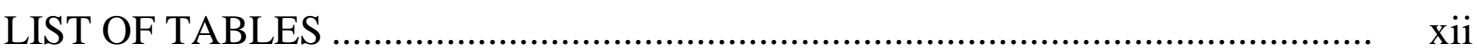

CHAPTER

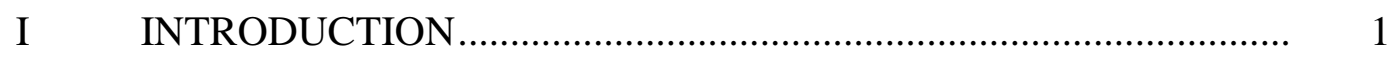

Current Model Systems .............................................................. 1

The Domestic Dog as a Model ....................................................... 6

Canine Mammary Cancer.............................................................. 9

MicroRNAs ............................................................................ 17

Oncomirs and Breast Cancer........................................................ 21

II MATERIALS AND METHODS ……………………………........ 29

Canine miRNA Search .............................................................. 29

RNA Isolation ..................................................................... 29

Proof of Principle Experiments ...................................................... 30

Oncomir Experiments ............................................................... 32

III PROOF OF PRINCIPLE EXPERIMENTS ……................................. 34

Comparative Bioinformatics ........................................................ 34

Introduction to the miR17-92 Cluster............................................ 36

Results and Discussion ............................................................. 37

Conclusions ............................................................................. 45 
CHAPTER $\quad$ Page

IV CANINE MAMMARY ONCOMIR STUDY ................................. 47

Introduction .............................................................. 47

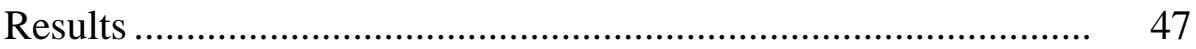

Discussion ............................................................... 52

V CONCLUSIONS AND FUTURE STUDIES ............................... 61

Summary ...................................................................... 61

Conclusions and Future Directions ......................................... 62

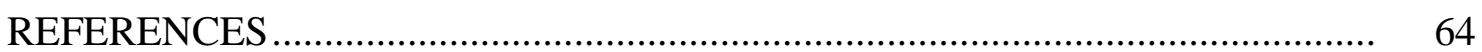

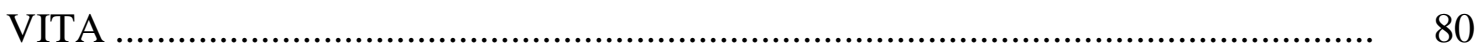




\section{LIST OF FIGURES}

FIGURE Page

1 MicroRNA Biogenesis ............................................................... 19

2 Proposed Mammalian RNAi Pathways .............................................. 28

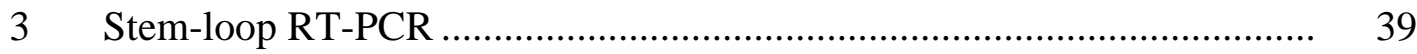

$4 \quad$ Standard Dilution Curves ................................................................. 41

$5 \quad m i R$ 17-92 Expression ............................................................. 43

$6 \quad$ Mammary Oncomir Expression …...................................................... $\quad 50$ 


\section{LIST OF TABLES}

TABLE Page

$1 \quad$ Breast Cancer Model Comparison ......................................................... 5

2 Canine Mammary Cancer vs. Human Breast Cancer............................. 8

3 Incidence Reports of Canine Mammary Cancer ................................. 10

$4 \quad$ Oncomirs in Breast Cancer .................................................................. 25

$5 \quad$ DOGmi Data .......................................................................... 35

6 Correlation Values for the $m i R$ 17-92 Cluster..................................... 41

$7 \quad$ miRNA Research in Mammary Cancer............................................... 48

8 Mammary Oncomirs Conservation Comparison................................... 49

$9 \quad$ P-values for Total and Subtype Analysis ......................................... 51 


\section{CHAPTER I}

\section{INTRODUCTION}

The American Cancer Society estimates that 240,510 women will be diagnosed with breast cancer in 2007, making it the most frequently diagnosed cancer in American women (American Cancer Society 2007). Another 40,460 will lose their battles with this disease (American Cancer Society 2007) that has become synonymous with the color pink and captured the attention and hearts of the public over the last two decades. Few can say that breast cancer has not directly or indirectly affected their lives. While research continues to progress, and survival rates improve, much work is left undone and many questions remain unanswered. Part of the investigation into breast cancer's mechanisms involves the use of models. Scientists have used the mouse (Mus musculus), rat (Rattus norvegicus), xenografts, and in vitro models with great success. Cellular pathways, new treatments and genetic aberrations have been elucidated with the aide of these models. However, each approach has limitations, and thus the search continues for novel and improved models that more accurately represent human breast cancer.

\section{Current Model Systems}

Cell lines, genetically engineered mice, and xenografts are the most common

This dissertation follows the style of Mammalian Genome. 
model systems used in breast cancer research. Each system has its own advantages and disadvantages, allowing researchers to investigate different parts of the puzzle that is breast cancer. Because cancer is a complex and heterogeneous disease, multiple systems are needed to elucidate progression of the disease and validate hypotheses.

Researchers would be lost without cell lines. Breast cancer lines from both human and rodents are available, and many lines are immortalized. An unending supply of protein, RNA, and DNA is a great advantage and allows for experiments to be replicated in mass. Cell lines are relatively inexpensive to maintain, and are easily manipulated both genetically and chemically. Human cell lines provide more direct subject evidence and confer the advantage of being directly from the species of study, providing more directly applicable answers. Cell lines can also be transplanted into rodents using xenographs, enabling an in vivo study. There are also different lines established that mimic many of the different subtypes of breast cancer. Unfortunately, a single cell line, which is usually derived from a single cell type, does not recapitulate a typical primary tumor which consists of multiple cell types (epithelial, stromal, vascular, immune, etc.) with multiple aberrations. Thus, one cell line cannot mimic the highly heterogeneous environment that is found in breast tumors (Vargo-Gogola and Rosen 2007). Genome copy number abnormalities are much more common in tumors than in cell lines (Neve et al. 2006). In addition, primary cell lines which are more representative of actual tumor cell life are difficult to cultivate and only survive for a few passages. Cell lines are ideal for studies examining signal pathways and gene regulation, 
but resulting data has to be confirmed in an in vivo model before application to human cancers.

Laboratory rodents are found in nearly every research institution because rapidly evolving genetic technology has enabled the production of hundreds of rodent lineages, each with a particular phenotype of interest. The complete genome sequence and annotated assembly is available for the mouse and rat, and both of these mammals show high levels of conservation with the human genome (Gibbs et al. 2004; Waterston et al. 2002). Some strains of mice are slightly more prone to tumors in general, but breast cancer researchers typically use several genetically manipulated murine models. Mammary tumors in the rat are mainly studied through chemically induced approaches in breast cancer labs (Vargo-Gogola and Rosen 2007). Their short life-span and large litter sizes are needed to carry out multiple-generation studies to identify heritable markers. Mice are easy to breed, and matings can be manipulated and replicated. There are a few disadvantages to this model system as well. Tumors seem to have different tissue origins as compared to the human, and the tumors have fewer chromosomal abnormalities (Vargo-Gogola and Rosen 2007). Mice strains are highly inbred, and have a metabolic rate that is seven times higher than that of the human (Dennis 2006). The ends of murine chromosomes (telomeres) are longer than the humans', because the telomerase activity is higher (Dennis 2006). And finally, mice undergo $10^{5}$ fewer cell divisions during their lifetime as compared to the human (Dennis 2006).

Another major complication to the mouse model is the use of the Mouse Mammary Tumor Virus (MMTV). Often the promoter of this endogenous murine 
retrovirus is used to overexpress a certain gene in a genetically modified mouse (VargoGogola and Rosen 2007). The virus itself is an example of the high load of pro-viruses that are found in the mouse model that are not seen in the human. To date a virus has not been associated with human breast cancer, although the relationship between the human papillomavirus and cervical cancer is documented in humans (Walboomers et al. 1999). One advantage to the induced tumor model is the ability to study how the tumor is initiated. Other spontaneous models do not offer this advantage.

Xenografts consist of an injection of cells into a live animal, usually a rodent, in order to study the actions of the cells in an in vivo environment. These are often used in metastasis research, and offer excellent insight into invasion properties and progression studies (Vargo-Gogola and Rosen 2007). However, human cells may act differently in a rodent environment than they do in a human environment, limiting the insights that can be made.

All in all, these models are diverse and useful, each providing a different side to the cancer story. However, in the currently used breast cancer models the tumors arise by methods such as mutagens or viral promoters that are not present in human breast tumor formation. Therefore a natural system of tumor induction would open a new door into breast cancer research. The collective disadvantages, summarized in Table 1, encourage researchers to keep looking for another, better system. 
Table 1. Breast Cancer Model Comparison.

\begin{tabular}{|c|c|c|}
\hline Model & Advantages & Disadvantages \\
\hline Cell lines & $\begin{array}{l}\text { Multiple lines available from both } \\
\text { rodent and human breast cancers } \\
\text { Immortalized lines are easy to distribute, } \\
\text { propagate, and store } \\
\text { Cells can be genetically and chemically } \\
\text { manipulated } \\
\text { Helpful in studying proliferation and } \\
\text { signaling pathways }\end{array}$ & $\begin{array}{l}\text { Tumor cells are homogeneous, while } \\
\text { actual tumors are heterogeneous } \\
\text { Finding must be validated in an in vivo } \\
\text { model } \\
\text { Gene copy number aberrations are lower } \\
\text { in cell lines than in tumors } \\
\text { Primary cell lines are difficult to initiate } \\
\text { and stabilize }\end{array}$ \\
\hline Xenograft & $\begin{array}{l}\text { Allows the study of either primary or } \\
\text { manipulated cells in an in vivo } \\
\text { environment } \\
\text { Excellent for studying invasion and } \\
\text { metastasis }\end{array}$ & $\begin{array}{l}\text { Human cells may not act the same way } \\
\text { in a rodent environment as they would } \\
\text { in a human environment }\end{array}$ \\
\hline Mouse & $\begin{array}{l}\text { Easy to breed, short life-span, and large } \\
\text { litter sizes } \\
\text { Complete genome sequenced } \\
\text { Genetically manipulated to exhibit } \\
\text { specific and desired breast cancer } \\
\text { phenotypes } \\
\text { Most commonly used laboratory animal }\end{array}$ & $\begin{array}{l}\text { For both rodent models: } \\
\text { Higher metabolism and telomerase } \\
\text { activity as compared to the human } \\
\text { Tumors used in mammary research are } \\
\text { induced; tumor origin is often in } \\
\text { different tissues than in the human and } \\
\text { with fewer chromosomal abnormalities } \\
\text { Undergo fewer cell divisions in their } \\
\text { lifetime versus the human } \\
\text { Smaller anatomy/sample collections } \\
\text { Highly inbred } \\
\text { Tumor inducing viruses (MMTV) } \\
\text { For the rat: } \\
\text { No knockout strains have been created }\end{array}$ \\
\hline Dog & $\begin{array}{l}\text { Spontaneously occurring mammary } \\
\text { tumors } \\
\text { Share the same environment as humans, } \\
\text { often serving as sentinels for } \\
\text { environmental carcinogens } \\
\text { Physically and genetically more similar } \\
\text { to humans than either rodent model } \\
\text { Complete genome sequenced } \\
\text { Excellent health care facilities and } \\
\text { medical records available with extensive } \\
\text { pedigrees } \\
\text { Shorter life-spans than humans and large } \\
\text { litter sizes } \\
\text { Large general population that is outbred }\end{array}$ & $\begin{array}{l}\text { Transgenic models are not available } \\
\text { Dependence on client owned animals } \\
\text { may limit sample collections }\end{array}$ \\
\hline
\end{tabular}




\section{The Domestic Dog as a Model}

One underused mammalian system is that of the domestic dog, Canis familiaris. For centuries the relationship between dog and man has been documented, but these two share more than just a common bond of friendship and loyalty. The domestic dog is genetically closer to the human than any of the previously mentioned models (Kirkness et al. 2003). This discovery was made possible when the complete genomic sequence of the dog was made publicly available with $1.5 \mathrm{X}$ coverage in of the poodle in 2002 (Kirkness et al. 2003). The currently available sequence of the boxer, Tasha, has a 7.5X coverage (Lindblad-Toh et al. 2005). This means that this genome sequence was so complete, that the "gaps" present in the genome were sequestered to autosomes 2, 11, and 16 out of the 36 pairs of autosomes and 2 sex chromosomes present in the canine karyotype. In addition to the karotype and sequence, detailed linkage and radiation hybrid (RH) maps are available and widely used (Breen et al. 2004; Guyon et al. 2003). Advances in computational analysis now allow researchers to critically evaluate and compare genomes across species to identify and investigate potential areas of interest, such as orthologous genes and conversed non-coding regions.

Despite the fact that the dog's ancestor diverged 93 million years ago from Euarchontaglires, the lineage that includes rodents and primates in the evolution tree (Murphy et al. 2001; Springer et al. 2003), the genome structure of the dog shows greater homology and conservation with the human as a result of the faster evolutionary rates observed in rodents (Wildman et al. 2007). The physiology of the domestic dog provides model advantages as well. The metabolism and cell kinetics of the dog have 
greater similarity with the human, than those of rodents (Lana et al. 2007). Thus both surgical and dosage studies can be more directly compared to human medicine. While body size of the dog varies greatly, all breeds are bigger than rodents used in research providing larger organs and tissues from which samples can be taken and analyzed.

One of the greatest advantages to cancer studies, however, is that fact that tumors occur spontaneously in the domestic dog and have a similar progression to human breast tumor malignancies. By avoiding chemical or genetic modifications to induce cancer (as is sometimes done in rodent models), the canine oncology model provides a "purer" example of the initiation and progression mechanisms of cancer cells. Since pets share our environment and often our diet, dogs can and have acted as sentinels for carcinogens. The dog's shorter lifespan and large litter sizes allow for clinical trials that are vastly shorter than those in the human. In addition, their population structure mimics that of the human, as they are generally outbred, but have subpopulations that underwent significant bottlenecks followed by inbreeding (Parker and Ostrander 2005). Breed clubs often include highly inbred dogs with extensive pedigrees which are ideal study populations to tease out causative mutations or rare chromosomal abnormalities responsible for particular diseases. Most relevant to the work presented in this dissertation however, is the fact that veterinary medical care has achieved great advances in order to make canine healthcare second to that of the human (Ostrander et al. 2000). Advances made in medical records and equipment have created in the opportunity to study and trace specific diseases, including canine mammary cancer. Table 2 compares the presentation of human breast cancer to canine mammary cancer. 
Table 2. Canine Mammary Cancer vs. Human Breast Cancer.

\begin{tabular}{|c|c|c|}
\hline & Human & Canine \\
\hline $\begin{array}{l}\text { Statistics } \\
\text { Incidence } \\
\text { Overall lifetime risk }\end{array}$ & $\begin{array}{l}\sim 100 / 100,000 \\
16 \%\end{array}$ & $\begin{array}{l}\sim 260 / 100,000 \\
2-20 \%\end{array}$ \\
\hline Mammary Physiology & 2 breasts & 2 chains of 5 glands \\
\hline Cellular Origin & Epithelial & Epithelial \\
\hline Frequent Metastasis Site & Lymph nodes and Lung & Lymph nodes and Lung \\
\hline $\begin{array}{l}\text { Inflammatory Carcinoma } \\
\text { Subtype }\end{array}$ & Yes & Yes \\
\hline $\begin{array}{l}\text { Molecular Changes: } \\
\text { Genetic mutations/Aberrant } \\
\text { expression profiles } \\
\text { (BRCA1, c-erbB-2, etc.) } \\
\text { p53 mutations } \\
\text { Chromosomal abnormalities } \\
\text { in tumor cells }\end{array}$ & $\begin{array}{l}\text { Yes } \\
\sim 20-25 \% \\
\text { Yes }\end{array}$ & $\begin{array}{l}\text { Yes } \\
\sim 17 \% \\
\text { Yes }\end{array}$ \\
\hline $\begin{array}{l}\text { Risk Factors: } \\
\text { Increased age } \\
\text { Female sex } \\
\text { Familial history } \\
\text { Sex hormone exposure } \\
\text { Obesity } \\
\text { Reduction of risk by } \\
\text { early pregnancy } \\
\end{array}$ & $\begin{array}{l}\text { Yes } \\
\text { Yes } \\
\text { Yes } \\
\text { Yes } \\
\text { Yes } \\
\text { Yes }\end{array}$ & $\begin{array}{l}\text { Yes } \\
\text { Yes } \\
\text { Yes } \\
\text { Yes } \\
\text { Yes } \\
\text { Not shown so far }\end{array}$ \\
\hline $\begin{array}{l}\text { Effective Treatments } \\
\text { Surgery } \\
\text { Chemotherapy } \\
\text { Radiation } \\
\text { Anti-estrogen treatments }\end{array}$ & $\begin{array}{l}\text { Yes } \\
\text { Yes } \\
\text { Yes } \\
\text { Yes }\end{array}$ & $\begin{array}{l}\text { Yes } \\
\text { No } \\
\text { Not studied } \\
\text { No }\end{array}$ \\
\hline
\end{tabular}




\section{Canine Mammary Cancer}

Incidence

It is estimated, that there are over 74 million household dogs in the United States alone. Because of advances in both human and veterinary medicine, the canine population, like the human population, is living longer, and this trend is one of the suggested theories of the rise in cancer in pets over the last few years (Lana et al. 2007). The rise in cancer could also be attributed to the technology that is now available, allowing for a more rapid and accurate diagnosis. Canine mammary tumors are the most prevalent neoplasm in the intact bitch (Sorenmo 2003). Multiple studies (summarized in Table 3) have been undertaken to estimate the actual incidence values with conflicting results. Approximately 260 out of every 100,000 dogs in the United States will be affected by mammary cancer every year if left intact (Dorn et al. 1968; Moulton et al. 1986). Analyzing the records of a pet-insurance company in the United Kingdom showed a similar yearly rate of incidence at 205 out of 100,000 dogs (Dobson et al. 2002). In contrast, a study of over $80,000 \mathrm{dogs}$ in the Swedish population found an incidence of 111 cases out of every 10,000 dog years at risk (Egenvall et al. 2005). Most investigations into incidence agree that several breeds have higher rates of mammary. cancer suggesting a hereditary link, these include the poodle, English springer spaniels, Brittany spaniels, cocker spaniels, English setters, pointers, German shepherds, Maltese, Yorkshire terriers, dachshunds, Golden retrievers and Doberman pinchers (Egenvall et al. 2005). 
Table 3. Incidence of Canine Mammary Cancer. Estimations of dogs diagnosed/year are summarized below.

\begin{tabular}{l|l}
\multicolumn{1}{l}{ Incidence } & \multicolumn{1}{l}{ Country } \\
\hline $260 / 100,000$ & United States \\
\hline $205 / 100,000$ & United Kingdom \\
\hline $111 / 10,000$ & Sweden \\
\hline
\end{tabular}

While it was estimated that $48 \%$ of the canine mammary tumors are benign, the remaining 52\% are malignant (Fidler and Brodey 1967). However, recent literature places the malignancy rate anywhere from 41-53\% (Fidler and Brodey 1967; Gilbertson et al. 1983). There is however, a very high recurrence rate, in that half of the tumors treated with surgery, later regenerate the tumor or develop a distant metastasis (Fidler and Brodey 1967). It is estimated that American female dogs have a 2-20\% lifetime risk of developing canine mammary cancer at some point in their lives (Dorn et al. 1968; Moulton et al. 1986). Recent work has shown a higher incidence of malignant tumors in large dogs $(58 \%)$ versus the small breeds (25\%) (Itoh et al. 2005). This work is controversial though, and has yet to be further confirmed.

\section{Pathology and Treatment}

Mammary tumors in the dog are either benign or malignant, and within these two classifications are several subtypes dependent upon their tissue of origin (e.g., epithelial, mesenchymal, or myoepithelial), cellular structure, invasiveness and exact location (e.g., duct, lobules, etc.) (Lana et al. 2007). As in human breast cancer, most canine mammary 
tumors are epithelial in origin (Sorenmo 2003). Approximately 65-70\% of the canine mammary tumors occur in the caudal $4^{\text {th }}$ or $5^{\text {th }}$ gland, and more than $60 \%$ of cases have more than one tumor present in the mammary chain at the time of diagnosis (Benjamin et al. 1999; Fowler et al. 1974). Canine mammary tumors primarily metastasize to the sublumbar, sternal and prescapular lymph nodes and to the lungs; however, metastasis to the liver and kidneys is not uncommon, while bone metastasis is rare (Lana et al. 2007; Misdorp and den Herder 1966).

Inflammatory mammary carcinoma (IMC) is a particularly aggressive form of mammary cancer found to only naturally occur in the human and the dog (Lana et al. 2007). This subtype accounts for $17 \%$ of malignant canine cases and is characterized by poorly differentiated, estrogen receptor negative cells (Pena et al. 2003a; Pena et al. 2003b; Perez Alenza et al. 2001). IMC rapidly invades the lymphatic system and metastasizes, resulting in very low and short survival times (Lana et al. 2007).

While several treatments exist, surgical removal of the tumor is the most common approach, but as previously mentioned, has only $\sim 50 \%$ success rate (Fidler and Brodey 1967). Surgical therapies contain vast variances as well, ranging from simple lumpectomies, recommended for small, non-invasive tumors to radical uni- or bilateral chain mastectomies, recommended for large, multiple, invasive cases (Lana et al. 2007). There is ongoing debate as to whether radical chain mastectomies or local excisions are the better course of action, but the majority of investigations have shown no difference in reoccurrence or survival rates, as long as the entire neoplastic tissue is removed (Chang et al. 2005; MacEwen et al. 1985). 
Chemotherapy following surgical excision is the predominant choice of human physicians to treat breast cancer (Dickson et al. 2005). Unfortunately, this course of therapy is not widely accepted in veterinary practice as an effective course of action. Doxorubicin has been studied in both in vitro and in vivo experiments in the domestic dog with moderate success (Hershey et al. 1999; Karayannopoulou et al. 2001; Sartin et al. 1993; Simon et al. 2006). Two studies have found that Doxorubicin effectively prolongs survival times of patients with particularly high grade mammary tumors and in cases with pulmonary metastasis (Hershey et al. 1999; Simon et al. 2006). One investigation showed that treatment with cyclophosphamide and 5-fluouroucil after surgery prolonged survival by an average of 18 months (Karayannopoulou et al. 2001). This data is promising, but more and larger studies must be completed and published before the standard treatment protocol will change.

Other human treatments, such as radiation therapy and biologic response modifiers have either not be tested or have not proven effective in canine cases. Radiation therapy, which is used in humans when breast-sparing surgery is performed, may be a key player in low recurrence rates, but, to date, canine mammary cancer case studies using radiation therapy have not been published. Biologic response modifiers, such as levamisole, lipo muramyl-tripeptide phosphatidylethanolamine, and Corynebacterium parvum with bacillus Calmette-Guérin, have not proven effective when tested in canine mammary cancers (MacEwen et al. 1985; Parodi et al. 1983). Antiestrogen therapies, such as tamoxifen, are not recommended as treatment modalities in canine cancers (Lana et al. 2007). While antiproliferative activity was 
detected in canine in vitro studies, multiple clinical trials have shown devastating sideeffects when used on dogs such as incontinence, signs of estrus, fluid and infections of the uterus or urinary tract, swelling of the vulva, and vaginal discharge (Morris et al. 1993). Hormones do play a clear role in canine cancer, though. It is irrefutable that ovariohystorectomies (OHEs) preformed prior to the first estrus cycle reduce the risk of canine mammary cancer. If the OHE is done before the first estrus, there is a $0.5 \%$ risk of mammary cancer (Schneider et al. 1969). The risk rises to $8 \%$ if the OHE is spayed after the first estrus, and 26\% if spayed after the second estrus (Schneider et al. 1969). However, OHE as a treatment in dogs suffering from mammary cancer does not seem to result in longer survivals (Morris et al. 1998; Yamagami et al. 1996). Although, one retrospective study did show an increase in survival time if the $\mathrm{OHE}$ is performed in the two years before the first malignant tumor removal (Sorenmo et al. 2000). Overall, later spaying does not seem to reduce malignant tumor survival or incidence.

The two key hormones in both human and canine mammary cancer studies are estrogen and progesterone. Estrogen is known to stimulate ductal growth, while progesterone and synthetic progestins such as chlormadine acetate and medroxyprogesterone acetate are known to induce lobuloalveolar mammary development and hyperplasia of secretory and myoepithlial elements (Lana et al. 2007). The level of estrogen receptors (ER) and progesterone receptors (PR) differ between normal, benign and malignant canine mammary tissues. In a study of 85 cancer and 10 normal mammary tissue samples from 57 dogs, immunohistochemistry was used to detect receptors (Millanta et al. 2005). 100\% of the normal and $95 \%$ of the benign 
samples showed strong ER staining, while $62 \%$ of invasive tumors showed some ER staining and $38 \%$ of invasive tumors showed poor to no ER staining. PR staining was lower in all tumors versus normal mammary tissue. Another study used immunohistochemistry to analyze 228 tumors from 100 dogs (de Las Mulas et al. 2005). $96 \%$ of the benign tumors showed staining for either PR or ER, while only $66 \%$ of the malignant tumors showed any staining. $100 \%$ of the cases where lymph node metastasis was detected were both ER and PR negative. Other studies corroborate with the general consensus that benign canine mammary tumors and normal canine mammary tissue have higher amounts of estrogen receptors than malignant canine mammary tumors (de Las Mulas et al. 2005; Donnay et al. 1995; Illera et al. 2006; Kumaraguruparan et al. 2006; MacEwen et al. 1982; Millanta et al. 2005; Nieto et al. 2000; Queiroga et al. 2005b; Rutteman et al. 1988b; Sartin et al. 1992). The fact that most canine malignant tumors seem to lose their hormone dependence during their progression to malignancy makes them an ideal model for human non-hormone dependent breast cancers.

The production or injection of progesterone is also known to increase the incidence of benign mammary tumors in the dog, with only one report suggesting it may also increase the incidence of malignant tumors (Stovring et al. 1997). This increase may be linked to the increase in secretion levels of growth hormone in human and canine mammary tissue when progesterone levels rise. Higher progesterone concentrations also coincide with rises in insulin-like growth factors I and II (IGF-I and IGF-II) in the human, mouse and dog, as well as in canine mammary tumor cell line studies (Mol et al. 
1997). The rise in IGF is also implicated in cell proliferation and tumorigenesis roles as well (Mol et al. 1997).

Genetics and Other Risk Factors

Predisposition in certain breeds indicates that there may be a genetic component to canine mammary tumor development. Like human oncology studies, several genetic links have been established in the dog model, many of which have homologs in the human genome. P53 is the most commonly mutated gene in human cancers (Bourdon 2007). When investigated using canine mammary tumors samples, several mutations have been documented in the canine homolog of P53 (Chu et al. 1998; Van Leeuwen et al. 1996; Veldhoen et al. 1999). Mutations of this major tumor suppressor gene are estimated to have an incidence of $17 \%$ in canine mammary cancers, with only one germline mutation documented (Veldhoen et al. 1999). 20-25\% of invasive human breast cancers are predicted to have a P53 mutation(Lacroix et al. 2006). When comparing expression of $P 53$, one study used multiple human antibodies and found that 15 out of 20 mammary tumors exhibited an increase in expression of mutant p53 (Haga et al. 2001).

Other genes, such as BRCAl and the ras family have also been studied in the dog (Castagnaro 1995; Nieto et al. 2003). While there are no reports of mutations in the ras family or increased expression of ras, mutations have been documented in BRCAI in the $\operatorname{dog}$ (Nieto et al. 2003). BRCAl was cloned and sequenced because of the genetic link found in human breast cancer (Miki et al. 1994). The loss of this gene in canine studies coincides with increased amounts of cell proliferation and ER negative staining (Nieto et 
al. 2003). When looking at the protein BRCA1, normal epithelial tissue shows nuclear staining, while tumors show mainly cytoplasmic staining, a phenomenon also documented in human studies (Nieto et al. 2003).

The oncogene $c$-erbB-2 has been documented to play a role in human breast cancer (Iwata 2007). Specifically it has been shown to be overexpressed in cancers that respond well to Herceptin ${ }^{\mathrm{TM}}$ (i.e. trastuzumab) because of its interaction with the receptor gene HER2 (Iwata 2007). Canine studies have shown increased levels of both the protein and mRNA of $c-e r b B-2$ in malignant but not in normal or benign tissues (Ahern et al. 1996; Dutra et al. 2004; Rungsipipat et al. 1999a). The human oncogenes COX-2 and $c$-yes- 1 have also been documented to be aberrantly expressed in canine mammary cancers (Dore et al. 2003; Heller et al. 2005; Miyoshi et al. 1991; Queiroga et al. 2005a; Rungsipipat et al. 1999a; Rungsipipat et al. 1999b).

Four heat shock proteins (Hsp27, Hsp72, Hsp73, and Hsp90) were analyzed using canine mammary tissue from 3 normals and 30 malignant cases (Romanucci et al. 2006). Hsp27, Hsp72 and Hsp90 were found to be overexpressed in tumors with a suggested role in carcinogenesis, while Hsp73 was suggested to play a role in cancer invasiveness. Immunohistochemical studies showed that proliferating cell nuclear antigen, Bcl-2, p53, and ER expression is increased in canine mammary cancer versus normal tissue, while cytokeratin expression is decreased in the tumors (Kumaraguruparan et al. 2006). The profile the staining created was mimicked using human samples. DNA aneuploidy has also been studied in mammary tumors resulting in detections of deletions, trisomies, fusions, translocations and other cytogenetic 
anomalies that likely play a role in the cancer progression (Hellmen et al. 1993; Rutteman et al. 1988a).

Other risk factors for canine mammary cancer include sex (obvious increased incidence in females), age (greater than 6 years of age) and obesity (Egenvall et al. 2005; Hellmen et al. 1993; Laumbacher et al. 2006; Perez Alenza et al. 1998; Sonnenschein et al. 1991). Studies have shown an increased risk of mammary cancer, if dogs are overweight when they are 1-2 years of age, regardless of whether they are intact or spayed (Perez Alenza et al. 1998). All three risk factors are also found to be of concern in the human. The reduction in the incidence of mammary cancer after an early age of pregnancy that has been documented in human studies has not been proven to be an effective risk reduction in dogs (Kurzman and Gilbertson 1986).

Prognosis

Currently, tumor size and grade are the leading prognostic indicators (Lana et al. 2007). A larger and more invasive tumor usually corresponds to a shorter survival time (Lana et al. 2007). Nuclear differentiation, a low cell proliferation index, clean lymph nodes, and positive ER status of the tumor are generally regarded with as good prognosis factors, and the reverse status is associated with a poor prognosis (Kurzman and Gilbertson 1986; Lana et al. 2007).

\section{MicroRNAs}

Recent work in oncology revealed that many genes encoding tumor suppressors and oncogenes are regulated by a special class of non-coding RNA genes, named 
microRNAs (Esquela-Kerscher and Slack 2006). MicroRNAs (miRNAs) are endogenously produced by eukaryotic organisms and invoke the RNA interference (RNAi) pathway to effect posttranscriptional gene silencing. The first miRNA was discovered in 1993 in Caenorhabditis elegans (Lee et al. 1993). This gene, lin-4, codes for a short RNA sequence that first forms a hairpin and is later processed to a short, 22 nucleotide, double-stranded RNA (dsRNA) segment that is complementary to the $3^{\prime}$ untranslated region (3' UTR) of the lin-14 transcript (Lee et al. 1993). Research showed that the lin-4 RNA product reduced expression of the lin-14 gene (Wightman et al. 1993). This miRNA gene was thought to be unique, but seven years later, another miRNA, let-7, was discovered in C. elegans (Reinhart et al. 2000). Subsequently, homologs of let-7 were found in the genomes of thirteen other organisms, giving the first clue to scientists that these conserved, novel genes play a crucial role in cellular pathways (Pasquinelli et al. 2000). To date, over 500 miRNA sequences have been identified in the human genome (Griffiths-Jones et al. 2006), and because of the great conservation between the human and canine genomes, it is highly probable that these sequences are also present in the canine genome. Thus, the approaches to investigate human miRNA expression can also be used to study miRNA expression in the dog. The methods by which miRNA genes are transcribed and the mechanisms by which they regulate translation have been studied extensively in mammalian cells (Ambros 2004; Aravin and Tuschl 2005; Bartel 2004).

The initial step for miRNA biogenesis is transcription by RNA polymerase II (Figure 1). The resulting RNA strand is designated a "primary-miRNA" (pri-miRNA). 


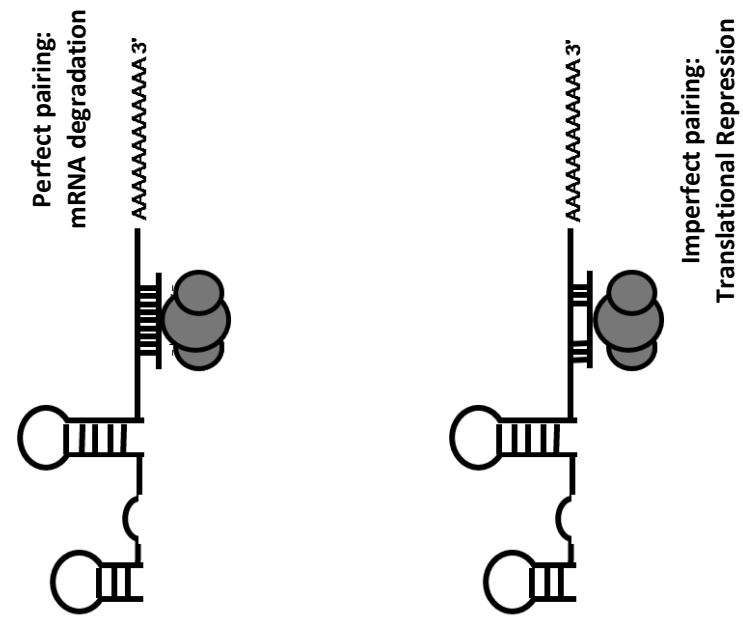

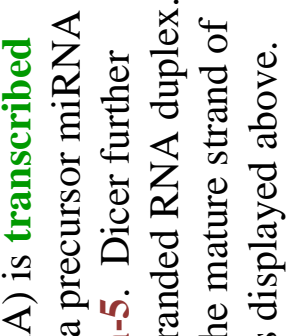

요

छ .

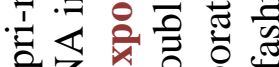

구웡

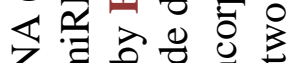

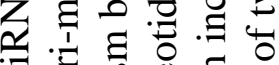

है

글

콕요.

四

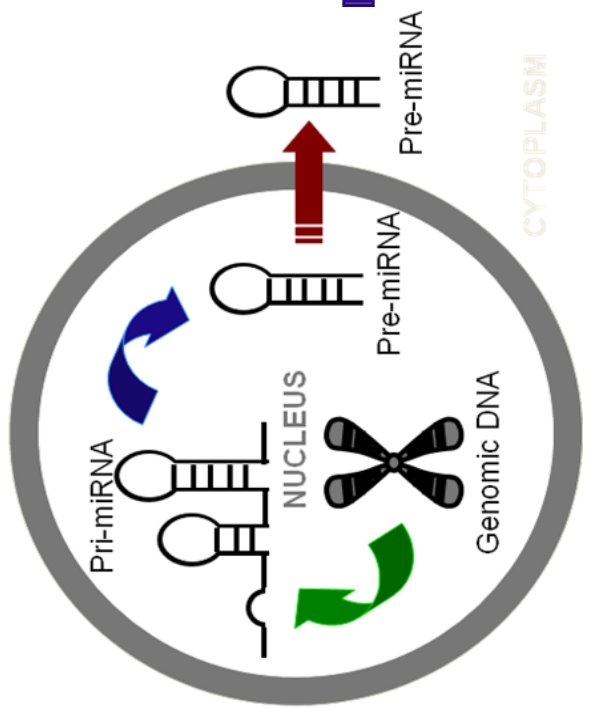

네요 $\infty$

E

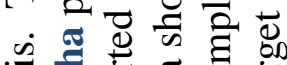

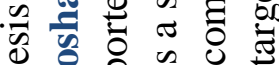

= के बै की

$\mathbb{\infty}_{0} 0$ च $\doteq$

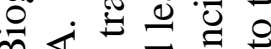

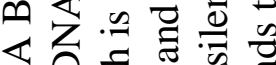

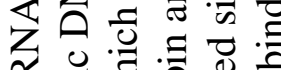

깅 응 可

을 胥

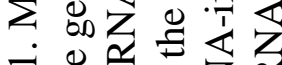

๖

$\exists \Xi \lesssim$

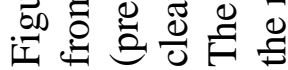


The single stranded RNA is modified, as are messenger RNAs (mRNAs), with a 5' cap and a polyadenylated tail. The pri-miRNAs are usually several kilobases in length and contain imperfect stem-loop structures that resemble hairpins. In step 2, the primiRNAs are recognized by Drosha, an enzyme that cleaves the RNA sequence, leaving only the hairpin structure behind. Drosha is a member of the RNase III family that characteristically leaves a two nucleotide overhang. The cleaved sequence is now referred to as a "precursor-miRNA" (pre-miRNA). The pre-miRNA is exported to the cytoplasm by a nuclear export factor, exportin 5 , as shown in step 3 . Once in the cytoplasm, another RNase III enzyme, Dicer, recognizes the pre-miRNA and further cleaves the hairpin to leave only a short, 18-24 nucleotide, dsRNA sequence (step 4). Finally, the RNA-induced silencing complex (RISC) incorporates the RNA duplex into its complex set of proteins during step 5. Only one strand remains associated and is used as a template to bind to the complementary portion of the target mRNA. The incorporated RNA segment is referred to as the mature miRNA. It is also interesting to note that many miRNAs target the 3'UTR of mammalian genes, a noncoding section of the gene. When RISC is associated with the appropriate, protein-coding mRNA sequence, the miRNA pathway can take one of two routes. In general, if the mRNA is completely complementary to the mature miRNA, the mRNA is degraded. If complementarity is not complete, the attachment to the mRNA is still able to reduce expression. The RISC complex's size and attachment location makes it difficult for translational machinery to stably attach to the mRNA (Thermann and Hentze 2007). Thus, protein production is reduced regardless of the route taken by the miRNA. 


\section{Oncomirs and Breast Cancer}

More than $50 \%$ of computational and experimentally identified miRNA genes are located in cancer-associated genomic regions, often called "fragile sites"(Calin et al. 2004b). Breaks and rearrangements of DNA occur more often in "fragile sites" and are thus areas of serious investigation. miRNAs that are associated with cancers are collectively referred to as "oncomirs." The miRNAs may act as either tumor suppressors by targeting the mRNA of an oncogene, or they can take on the reverse role of an oncogene by targeting the mRNA of a tumor suppressor. Because inhibition of translation can occur without perfect complementarity between the mature miRNA and the target mRNA, one miRNA can have several targets, and conversely, one mRNA may be targeted by several miRNAs. This makes functional studies a bit more complicated, especially since the expression profiles of miRNAs have tissue specificity. Several computational programs (miRanda, PicTar, TargetScan, etc.) exist to help predict likely targets and binding sites and have been used with success.

The miR17-92 cluster of miRNA genes are differentially expressed in several types of cancer, including human mammary cancer tissues (Hossain et al. 2006; Volina et al. 2006; Zhang et al. 2006). This specific cluster is made up of seven miRNA genes (miR-17-5p, miR-17-3p, miR-18, miR-19a, miR-19b, miR-20, miR-92) that arise from six miRNA precursors ( $m i R-17-3 p$ and $m i R-17-5 p$ share the same precursor). An investigation into gene copy number aberrations revealed that $21.9 \%$ of human breast cancers have the entire miR-17-92 cluster deleted (Zhang et al. 2006). Specifically, the miR-17-5p gene was recently shown to affect cell proliferation in mammary cancer by 
inhibiting the translation of the mRNA transcribed from Amplified in Breast Cancer 1 (AIB1), a tumor suppressor gene (Hossain et al. 2006). The same study also showed a very low expression of $m i R-17-5 p$ in breast cancer cell lines. Because of this action, it seems to fall into the category of a tumor suppressor miRNA. O'Donnell and colleagues revealed the oncogene $E 2 F 1$ to be another target of $m i R-17-5 p$ (2005), and Lu and colleagues showed a down regulation of miRNA in breast cancer samples (2005). However, a microarray study by Volina et al. revealed an upregulation of the same miRNA in breast cancer (2006). The differences could be explained by the different experimental techniques and analyses. In addition, tumor samples can contain heterozygosity among themselves. Thus, analyzing tumors by their specific pathology could account for differences in results as well.

There are five basic classifications of human breast tumors, and they include the following: Luminal A, Luminal B, HER2+, Basal-like, and Normal-like (Neve et al. 2006). By looking at the general profile miRNA expression in these five subtypes, Blenkiron and colleagues were able to classify 51 out of 93 primary breast tumors using a bead-based flow cytometry method (2007). Specifically, this study found a differential expression of $m i R-155$ between ER positive and negative rumors. In high grade (based upon size and invasion) tumors, the three miRNAs were found to be of interest: $m i R$ $106 b$ (a homolog of $m i R-17-5 p$ ), miR-93, and $m i R-25$. A microarray study by Iorio and colleagues compared 79 human cancerous samples to ten normal tissue samples and revealed expression profiles that were able to identify normal and cancerous breast tissue based upon the differential expression of four miRNAs: $m i R-21, m i R-145, m i R-155$, and 
$m i R-125 b$ (2005). These results were confirmed by Northern blotting. In addition, specific profiles were developed for several different factors involved in breast cancer including: ER/PR status, tumor grade, nodal involvement, vascular invasion, proliferation index and p53 expression. Microarray and quantitative real time PCR (qRT-PCR) was used by Mattie et.al. in their investigation of tumors expressing different combinations of the receptors: ErbB2, ER and PR (2006). Seven miRNAs were found to be expressed solely in the ErbB2 profile, including, let-7f and $m i R-10 b$. Four miRNAs were exclusive to the ER/PR status ( $m i R-142-5 p, m i R-200 a, m i R-205$, and $m i R-25)$.

Some labs have chosen to investigate individual miRNAs in order to determine particular targets and functions in breast cancer. Cimmino and colleagues recently confirmed that overexpression of $m i R-15 a$ and $m i R-16-1$ in a leukemic cell line model encourages tumor growth by posttranscriptionally suppressing the gene $B C L 2$, which plays a critical role in apoptosis (2005). miR-10b was found to target homeobox D10 (HOXD10), a gene that represses the expression of RHOC (Ma et al. 2007). When miR$10 b$ is expressed at high levels, the expression of RHOC, a pro-metastatic gene, increases; therefore, increased tumor invasion and metastasis occurs. Interestingly, the transcription factor Twist was also found to induce $m i R$ - $10 \mathrm{~b}$ expression by binding to its promoter. Another investigation revealed $m i R-200 c$ to target transcription factor eight (TCF8), which regulates E-cadherin expression (Hurteau et al. 2007). Estrogen receptor alpha has been shown to be regulated by both let-7d and miR-206 (Adams et al. 2007). Meanwhile, much attention has been given to $m i R-27 a$ and $m i R-27 b$. The former 
miRNA acts as an oncogene by regulating $M y t-1$ and the specificity proteins $\mathrm{Sp} 1, \mathrm{Sp} 2$ and Sp3, while the latter targets the oncogene, CYP1B1 (Mertens-Talcott et al. 2007; Tsuchiya et al. 2006).

The most investigated oncomiR is $m i R-21$. Because it has found roles in several cancers including glioblastoma, liver, pancreatic, and breast, several studies have investigated its expression and function (Blenkiron et al. 2007; Esquela-Kerscher and Slack 2006; Frankel et al. 2007; Iorio et al. 2005; Jiang et al. 2005; Kovalchuk et al. 2007; Lu et al. 2005; Mattie et al. 2006; Meng et al. 2007; Si et al. 2007; Silveri et al. 2006; Volinia et al. 2006; Zhang et al. 2006; Zhu et al. 2007). miR-21 consistently acts as an oncogene, and it is known to target the tumor suppressors: TPM1 (Tropomyosin 1) in breast cancer (Zhu et al. 2007) and PTEN in hepatocellular carcinomas (Meng et al. 2007). Recent work has also linked genes involved in p53's pathway (PDCD4, CDK6, and Cofilin2) to increased miR-21 expression (Frankel et al. 2007).

Simple expression studies are not the only investigations into miRNAs role in breast cancer. Epigenetic studies have also revealed interesting methods of regulation. 71 breast cancer specimens were analyzed and revealed a subset of miRNAs that undergo hypermethylation (Lehmann et al. 2007). In particular, miR-9-1 was found to be differentially hypermethylated in normal breast tissue and demethylated in cancerous samples (Lehmann et al. 2007). Additional studies are of course on-going and expanding every day, and this short review only covers the published data and is summarized in Table 4. The obvious role the miRNAs have in breast cancer has sparked projects across the country and across the globe. By identifying particular miRNAs 
Table 4. Oncomirs in Breast Cancer.

\begin{tabular}{|c|c|c|}
\hline Oncomir & Role in Breast Cancer & Reference(s)* \\
\hline$\overline{m i R-9-1}$ & hypermethylated in normal mammary tissue & 1 \\
\hline$m i R-10 b$ & $\begin{array}{l}\text { induced by Twist and targets } H O X D 10 \text {, a repressor of RHOC } \\
\text { downregulted in tumors (microarray); associated with invastion } \\
\text { and metastatsis; associated with ErbB2 status }\end{array}$ & $2,3,4$ \\
\hline $\begin{array}{l}m i R-15 a \\
m i R-16\end{array}$ & $\begin{array}{l}\text { regulates } B C L 2 \text { expression; copy number decreased in } \\
\text { breast tumors }\end{array}$ & 5,6 \\
\hline$m i R-17-92$ cluster & deleted in $21.9 \%$ of breast cancers & 7 \\
\hline$m i R-17-5 p$ & $\begin{array}{l}\text { tumor suppressor that targets } A I B 1 \text { and } E 2 F 1 \text {; separate } \\
\text { reports show an upregulation in some breast cancers }\end{array}$ & $8,9,10$ \\
\hline$m i R-21$ & $\begin{array}{l}\text { oncogene; targets TPM1 and several components of the } \\
\text { p53 pathway; higher expression in tumors }\end{array}$ & $\begin{array}{l}2,4,6,7,10 \\
11,12,13,14\end{array}$ \\
\hline$m i R-25$ & $\begin{array}{l}\text { upregulateded in high grade tumors; associated with } \\
\text { ER/PR status }\end{array}$ & 4,6 \\
\hline$m i R-27 a$ & $\begin{array}{l}\text { oncogene; targets } M y t-1 \text { and } \mathrm{Sp} 1, \mathrm{Sp} 2 \text { and } \mathrm{Sp} 3 \text {; histone is } \\
\text { acetylated }\end{array}$ & 15,16 \\
\hline$m i R-27 b$ & tumor suppressor; targets $C Y P 1 B 1$; histone is acetylated & 16,17 \\
\hline$m i R-93$ & upregulated in high grade tumors & 6 \\
\hline$m i R-106 b$ & upregulated in high grade tumors & 6 \\
\hline$m i R-125 b$ & downregulated in tumor samples & 2,4 \\
\hline$m i R-142-5 p$ & associated with ER/PR status & 4 \\
\hline $\operatorname{miR}-145$ & downregulated in tumor samples & 2,4 \\
\hline$m i R-155$ & $\begin{array}{l}\text { oncogene with differential expression between ER positive } \\
\text { and negative tumors }\end{array}$ & 4,6 \\
\hline$m i R-200 a$ & associated with ER/PR status & 4 \\
\hline$m i R-200 c$ & targets $T C F 8$ and therefore E-cadherin expression & 18 \\
\hline$m i R-205$ & associated with ER/PR status & 4 \\
\hline$m i R-206$ & regulates ER $\alpha$ & 19 \\
\hline let-7 family & $\begin{array}{l}\text { regulates ER } \alpha, R A S \text {, and } H M G A 2 ; 7 f \text { is repressed in tumors } \\
\text { associated with ErbB2 status }\end{array}$ & $2,6,19$ \\
\hline
\end{tabular}

*References: 1:(Lehmann et al. 2007); 2: (Iorio et al. 2005); 3: (Ma et al. 2007); 4: (Mattie et al. 2006); 5: (Cimmino et al. 2005); 6:(Blenkiron et al. 2007); 7: (Zhang et al. 2006); 8: (Hossain et al. 2006); 9: (O'Donnell et al. 2005); 10: (Lu et al. 2005); 11: (Zhu et al. 2007); 12: (Meng et al. 2007); 13: (Volinia et al. 2006); 14: (Frankel et al. 2007); 15: (Mertens-Talcott et al. 2007); 16: (Scott et al. 2006); 17: (Tsuchiya et al. 2006); 18: (Hurteau et al. 2007); 19: (Adams et al. 2007) 
involved in cancer, a list of target miRNA genes is being generated for RNAinterference (RNAi) gene therapy.

RNA Interference

The discovery of the RNAi pathway by Fire and Mello (Fire et al. 1998), a Nobel Prize winning effort, has opened doors to new treatment options by silencing genes that cause diseases. RNAi is an evolutionarily conserved process that leads to posttranscriptional suppression of gene expression. Among other functions, it is thought to serve as a natural defense mechanism against a variety of pathogens including viruses (Lecellier et al. 2005). Since the initial experiments in Caenorhabditis elegans which demonstrated sequence-specific gene silencing in response to double stranded RNA (Fire et al. 1998), numerous studies have been performed that clearly demonstrate RNAi is operational in most eukaryotic organisms. These findings were the impetus for many subsequent scientific experiments carried out in recent years. These investigations were directed towards characterizing RNAi machinery in various model organisms.

The use of RNAi as an experimental or therapeutic tool in mammalian systems was initially problematic. However, approaches have been developed that avoid nonspecific dsRNA responses and permit the exploitation of RNAi for sequence-specific silencing in mammalian cells. One such protocol involves the use of synthetically produced siRNAs of approximately 21 nucleotides in length that essentially mimic the cleavage products of Dicer. These siRNAs, that we plan to employ in our research have been shown to be highly effective when transfected in mammalian cells to induce sequence-specific gene silencing. This makes siRNAs a powerful experimental tool for 
probing gene function and expression (Elbashir et al. 2002). Alternatively, synthetically created short hairpin RNAs (shRNAs) designed to target specific genes can also be transfected into cells and enter the RNAi pathway. Both siRNAs and shRNAs are transient approaches, a more permanent option, would be to use actually incorporate a primary miRNA sequence into a cell's genome using a virus. Figure 2 summarizes the different approaches.

RNAi technology has rapidly become a molecular workhorse in functional genomic studies and is one of the most innovative approaches to studying gene function. Importantly, it is a new approach for the treatment and prevention of disease, and has emerged as the latest, most powerful technology in silencing expressed genes in eukaryotic organisms. The precise action of the RNAi cellular machinery in silencing specific gene expression allows investigators to analyze gene function in vivo and in vitro in ways not previously possible. 


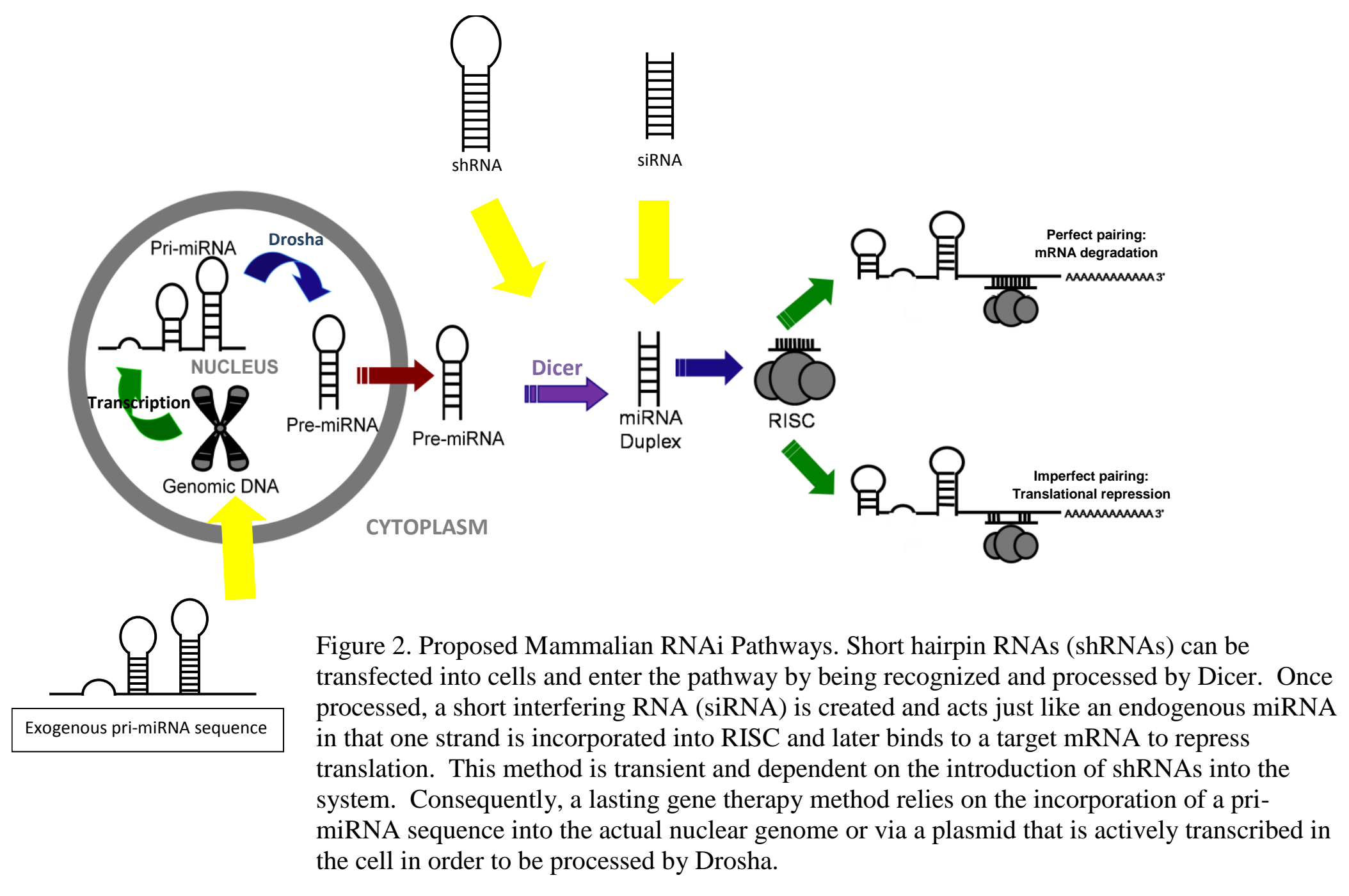




\section{CHAPTER II}

\section{MATERIALS AND METHODS}

\section{Canine miRNA Search}

All 447 human precursor sequences of the 9.0 Version of the Sanger miRNA Registry (http://microrna.sanger.ac.uk) were used to search for the homologous canine sequences using NCBI's BLAST search program (http://www.ncbi.nlm.nih.gov/genome/seq/BlastGen/BlastGen.cgi?taxid=9615). Identity percentage was calculated by dividing the number of matched bases by the total number of bases in the human precursor. Mature percentages were calculated by dividing the number of matches at the mature sequence by the total number of bases in the mature sequence. This search resulted in the identification of sixteen human precursor miRNA sequences (hsa-miR-17-3p, hsa-miR-17-5p, hsa-miR-18a, hsa-miR-19a, hsa-miR-19b, hsa-miR-20a, hsa-miR-92a, hsa-miR-15a, hsa-miR-16, hsa-miR-21, hsa-miR-29b, hsamiR-125b, hsa-miR-145, hsa-miR-155, hsa-miR-181b, and hsa-let-7f) that showed extreme sequence identity between the two genomes and which were selected for future study.

\section{RNA Isolation}

Tissue samples from the brain, heart, renal cortex, renal medulla, liver, and lung were collected from a mixed-breed, male dog and stored in RNAlater® (Ambion Inc., Austin, TX). Six primary canine mammary tumors were collected and used in this study. Tumor samples were stored in RNAlater. Ten normal mammary tissue samples were 
collected from healthy adult female dogs that underwent an elective ovariohysterectomy (OHE) through Texas A\&M University’s Veterinary Medical Teaching Hospital General Surgery Department with the proper permission from the university's Clinical Research Review Committee. At the conclusion of the OHE, a 1 centimeter incision was made over the most prominent mammary gland. A sample of mammary tissue approximately $3 \mathrm{~mm}$ x $10 \mathrm{~mm}$ was collected and stored in RNAlater ${ }^{\circledR}$ (Ambion Inc., Austin, TX). Procedures were all in compliance with TAMU's CRRC \#07-02.

Total RNA was isolated from all samples using the mirVana ${ }^{\mathrm{TM}}$ miRNA Isolation Kit (Ambion Inc.) following the manufacturer's recommended protocol. Samples were evaluated for quality and quantity using the NanoDrop ${ }^{\circledR}$ ND-1000 Spectrophotometer (NanoDrop Technologies, Wilmington, DE).

\section{Proof of Principle Experiments}

TaqMan® MicroRNA Assays (hsa-miR-17-3p, hsa-miR17-5p, hsa-miR-18a, hsa-miR-19a, hsa-miR-19b, hsa-miR-20a, and hsa-miR-92a) were used to reverse transcribe seven mature miRNA molecules to cDNA (ABI). For standard curve reactions, $300 \mathrm{ng}, 30 \mathrm{ng}, 3 \mathrm{ng}, 0.3 \mathrm{ng}$, and $0.03 \mathrm{ng}$ total lung RNA were used, and for all expression studies, $7 \mathrm{ng}$ of RNA were used. Each $15 \mu \mathrm{l}$ reverse transcription reaction contained: $5 \mu \mathrm{l}$ of total RNA diluted to the appropriate concentration, $1 \mathrm{X}$ TaqMan® MicroRNA RT primer, 0.25 U RNase inhibitor, 1X RT buffer, 3.33 U MultiScribe ${ }^{\mathrm{TM}}$ reverse transcriptase, and $1 \mathrm{mM} d \mathrm{dNPs}(\mathrm{ABI})$. The reverse transcription reactions were run in an Eppendorf MasterCycler (Westbury, NY) for 30 minutes at $16^{\circ} \mathrm{C}, 30$ minutes 
at $42^{\circ} \mathrm{C}, 5$ minutes at $85^{\circ} \mathrm{C}$, and then held at $4^{\circ} \mathrm{C}$. Controls included reactions with no template, no primer, and the RNU6B TaqMan® Assay (ABI), which codes for a small RNA that has been validated by ABI as an appropriate control and confirmed for sequence identity in the canine genome.

The reverse transcription products were diluted 1:15. The $20 \mu \mathrm{l}$ real time reaction contained $1.33 \mu$ l diluted RT product, $1 \mathrm{X}$ TaqMan ${ }^{\circledR}$ Universal PCR Master Mix (No AmpErase $\left.{ }^{\circledR} \mathrm{UNG}\right)$, and 1X TaqMan ${ }^{\circledR}$ assay, which contained the forward and reverse primers as well as the TaqMan® probe. Each reaction was run in triplicate on a 96-well plate. Reactions containing no reverse transcription product served as negative controls. Reactions were incubated in an ABI7000 Prism Sequence Detection System for 10 minutes at $95^{\circ} \mathrm{C}$, followed by 40 cycles of $95^{\circ} \mathrm{C}$ for 15 seconds and $60^{\circ} \mathrm{C}$ for one minute. After completion of the qRT-PCR, the threshold value was manually set above the baseline displayed in the amplification plot. Relative quantification of gene expression was evaluated by utilizing the comparative critical threshold $\left(\mathrm{C}_{\mathrm{T}}\right)$. The $\mathrm{C}_{\mathrm{T}}$ values for each mature miRNA reaction were subtracted from the respective $C_{T}$ value of the $R N U 6 B$ control, resulting in the $\Delta \mathrm{C}_{\mathrm{T}}$ value. The largest $\Delta \mathrm{C}_{\mathrm{T}}$ value was arbitrarily used as a constant that was subtracted from all other $\Delta \mathrm{C}_{\mathrm{T}}$ values to determine $\Delta \Delta \mathrm{C}_{\mathrm{T}}$ value. Fold changes were then generated for each mature miRNA by calculating $2^{-\Delta \Delta \mathrm{C}_{\mathrm{T}}}$. The products from real time reactions were cloned and verified by sequencing. Real time products were cleaned using $0.05 \mathrm{U}$ of shrimp alkaline phosphatase (Roche Applied Science, Indianapolis, IN) and 0.5 U of Exonuclease I (Epicentre Biotechnologies, Madison, WI) for a total reaction volume of $20 \mu 1$. Reactions were run 
on an Eppendorf Mastercycler for 30 minutes at $37^{\circ} \mathrm{C}, 15$ minutes at $80^{\circ} \mathrm{C}$, and then held at $4{ }^{\circ} \mathrm{C}$. Products were cloned into TOPO4 vectors and sequenced through use of universal M13 primers. The Big Dye Termination Sequencing Kit (ABI) was used according to the manufacturer's protocol. Sequencing was done using an ABI 3130 Genetic Analyzer, and the resulting sequences were aligned to known target sequences using CLUSTAL W (http://www.ebi.ac.uk/clustalw/).

\section{Oncomir Experiments}

TaqMan® MicroRNA Assays (hsa-miR-15a, hsa-miR-16, hsa-miR-17-5p, hsamiR-21, hsa-miR-29b, hsa-miR-125b, hsa-miR-145, hsa-miR-155, hsa-miR-181b, and hsa-let-7f ) were used to reverse transcribe ten seven mature miRNA sequences to cDNA (ABI). Each $15 \mu 1$ reverse transcription reaction contained: $5 \mu l$ of total RNA diluted to a $1.4 \mathrm{ng} / \mu$ l concentration, $1 \mathrm{X}$ TaqMan® MicroRNA RT primer, $0.25 \mathrm{U}$ RNase inhibitor, 1X RT buffer, 3.33 U MultiScribe ${ }^{\mathrm{TM}}$ reverse transcriptase, and $1 \mathrm{mM}$ dNTPs (ABI). The reverse transcription reactions were run in a BioRad thermocycler (Hercules, CA) for 30 minutes at $16^{\circ} \mathrm{C}, 30$ minutes at $42^{\circ} \mathrm{C}, 5$ minutes at $85^{\circ} \mathrm{C}$, and then held at $4{ }^{\circ} \mathrm{C}$. Controls included reactions with no template, no primer, and the RNU6B TaqMan® Assay (ABI), which codes for a small RNA that has been validated by ABI as an appropriate control.

The reverse transcription products were diluted $1: 15$. The $20 \mu 1$ real time reaction contained $1.33 \mu$ l diluted RT product, 1X TaqMan® Universal PCR Master Mix (No AmpErase $\left.{ }^{\circledR} \mathrm{UNG}\right)$, and $1 \mathrm{X}$ TaqMan ${ }^{\circledR}$ assay, which contained the forward and reverse 
primers as well as the TaqMan® probe. Each reaction was run in triplicate on a 96-well plate. Reactions containing no reverse transcription product served as negative controls. Reactions were incubated in an ABI7500 Prism Sequence Detection System for 10 minutes at $95^{\circ} \mathrm{C}$, followed by 40 cycles of $95^{\circ} \mathrm{C}$ for 15 seconds and $60^{\circ} \mathrm{C}$ for one minute. After completion of the qRT-PCR, the threshold value was automatically configured above the baseline displayed in the amplification plot. Relative quantification of gene expression was evaluated by utilizing the comparative critical threshold $\left(\mathrm{C}_{\mathrm{T}}\right)$. The $\mathrm{C}_{\mathrm{T}}$ values for each mature miRNA reaction were subtracted from the respective $\mathrm{C}_{\mathrm{T}}$ value of the $R N U 6 B$ control, resulting in the $\Delta \mathrm{C}_{\mathrm{T}}$ value. The largest $\Delta \mathrm{C}_{\mathrm{T}}$ value was arbitrarily used as a constant that was subtracted from all other $\Delta \mathrm{C}_{\mathrm{T}}$ values to determine $\Delta \Delta \mathrm{C}_{\mathrm{T}}$ value. Fold changes were then generated for each mature miRNA by calculating $2^{-\Delta \Delta \mathrm{C}_{\mathrm{T}}}$. Expression levels of normal samples were compared to cancerous samples using a standard MANOVA. 


\section{CHAPTER III}

\section{PROOF OF PRINCIPLE EXPERIMENTS*}

\section{Comparative Bioinformatics}

Countless investigations have used comparative genetics to elucidate orthologous genes. Because of the conservation found between the canine and human genomes (Kirkness et al. 2003), it was hypothesized that miRNA genes were also conserved. Conserved miRNA genes have been found in as distantly related organisms as plants, worms and mammals (Tanzer and Stadler 2004), thus a high sequence identity was predicted for miRNA genes shared between the canine and human genomes. The initial step for identification of canine miRNAs was a bioinformatics search that utilized the currently available genome sequence and the Sanger miRNA Database (Griffiths-Jones et al. 2006). All human precursor sequences listed in the database were aligned with the domestic dog sequence using the BLAST application available on NCBI's website (http://www.ncbi.nlm.nih.gov/genome/seq/BlastGen/BlastGen.cgi?taxid=9615).

Of the 447 human pre-miRNAs investigated, 268 were found to have a homolog in the canine genome. Table 5 lists the breakdown of conservation found among the homologs. 289 mature miRNA sequences were located in the homolgous pre-miRNAs. When the mature sequences were analyzed for sequence identity, 265 were found to be

*Reprinted in part from Gene 404, Boggs RM, Moody JA, Long CR, Tsai KL, Murphy $\mathrm{KE}$, Identification, amplification and characterization of miR-17-92 from canine tissue, 25-30, Copyright (2007), with permission from Elsevier. 
completely conserved. Since the mature miRNA segment is the functional element of the gene product that is responsible for binding to the target mRNA, it was expected to have a much higher conservation percentage, for it is much more intolerant of mutations.

Table 5. DOGmi Data. Human precursor sequences were computationally compared to the canine genome sequences using the BLAST feature of the NCBI website.

\begin{tabular}{|c|c|c|}
\hline $\begin{array}{c}\text { Type of } \\
\text { miRNA }\end{array}$ & $\begin{array}{c}\text { Canine/Human } \\
\text { \%Identity }\end{array}$ & $\begin{array}{c}\text { \# of } \\
\text { sequences }\end{array}$ \\
\hline Precursor & 100 & 50 \\
\hline & $95-99.9$ & 135 \\
\hline & $90-94.9$ & 51 \\
\hline & $<90$ & 32 \\
\hline Mature & 100 & 265 \\
\hline & $95-99.9$ & 17 \\
\hline & $90-94.9$ & 4 \\
\hline & $<90$ & 3 \\
\hline
\end{tabular}

All of the data recorded from the in silico search was recorded in a database named DOGmi. Human and canine chromosome locations are listed for each precursor available from the Sanger database Version 9.0, along with the percent of sequence 
identity, and the corresponding TaqMan ${ }^{\circledR}$ MicroRNA Assay that can be used to quantify the miRNA's expression levels.

A similar approach was undertaken by another laboratory. In addition to sequence identity, a program called RNAZ was employed to analyze the RNA's energy and structure. Rat and mouse genomes were also used in addition to the canine and human genome for comparison. The group established a publicly available database for their findings and refer to it as MiRMap.

\section{Introduction to the miR-17-92 Cluster}

miRNA genes are distributed throughout the genomes of both plants and animals.

They are often found in clusters and are located in almost every region of the mammalian genome including introns, exons, and the 3' UTR of genes. One specific cluster, $m i R-17-92$, has been widely studied in the human and other organisms. This cluster is evolutionarily conserved with homologs in Mus musculus, Rattus norvegicus, Canis familiaris, Xenopus tropicalis, Pan troglodytes, Takifugu rubripes, Tetraodon nigroviridis, and Danio rerio (Tanzer and Stadler 2004). One of the genes in the cluster, miR-92, even has homologs in the invertebrates C. elegans and Drosophila (Tanzer and Stadler 2004). Aberrant expression of this cluster has also been studied in multiple organisms and linked to several cancers (Hayashita et al. 2005; He et al. 2005; Hossain et al. 2006).

The purpose of the work reported herein was to (1) validate the use of Applied Biosystems Inc.’s (ABI’s) TaqMan ${ }^{\circledR}$ MicroRNA Assays (Foster City, CA), originally 
designed for human miRNAs, as a tool to study canine miRNA expression and (2) verify the expression of miRNA genes in canine tissues. To this end, human miRNA precursor sequences were used to identify putative canine miRNA genes by sequence identity. TaqMan® Assays were validated for use with canine miRNAs and expression of the canine $m i R-17-92$ cluster was evaluated in six different canine tissues of a normal mixed-breed dog.

\section{Results and Discussion}

Identification

According to the 9.1 version of the Sanger miRNA Registry, only six miRNAs have been identified in the canine genome (Griffiths-Jones et al. 2006; Xie et al. 2005). These canine miRNAs were identified through a computational search and have not been experimentally confirmed (Xie et al. 2005). As such, this study is the first to evaluate expression of miRNAs from canine tissues. Other investigations have characterized miRNA expression in the human, mouse, and pig (Chen et al. 2005; Fu et al. 2005; Hayashita et al. 2005; Lagos-Quintana et al. 2001; Lagos-Quintana et al. 2002; Sawera et al. 2005; Sempere et al. 2004). By identifying and validating a tool to study miRNA expression in the dog, both species-specific and comparative genomic data were obtained.

In order to study canine miRNA expression, identification of putative miRNA sequences was necessary. The miR-17-92 cluster has been characterized in vertebrates as well as invertebrates (Calin et al. 2004b; Houbaviy et al. 2005; Sawera et al. 2005; 
Tanzer and Stadler 2004). Importantly, genes within the $m i R-17-92$ cluster are associated with various human cancers which may be modeled in the domestic dog (EsquelaKerscher and Slack 2006; Hayashita et al. 2005; He et al. 2005; Hossain et al. 2006; Hwang and Mendell 2006; Thomson et al. 2006). For these reasons, the canine miR-1792 cluster was chosen for this investigation. The human $m i R-17-92$ precursor sequences (hsa-miR-17-3p, hsa-miR-17-5p, hsa-miR-18a, hsa-miR-19a, hsa-miR-19b, hsa-miR20a, and hsa-miR-92a) were used to search for the corresponding canine precursors. The miR-17-92 cluster, located on human autosome 13 , showed perfect sequence identity to a region on canine autosome 22 . The extent of conservation between the human and the $\mathrm{dog}$, as well as the presence of these genes in numerous other species, strongly suggests functional importance for this cluster of miRNA genes.

\section{Amplification and Validation of Canine miRNAs}

Of the various tools available to study miRNA expression, the TaqMan® MicroRNA assay (detailed in Figure 3) was chosen over northern blotting and alternative real time approaches for several reasons. Each TaqMan® assay uses primers and a fluorescent probe that are specific for a single, mature miRNA sequence. These primers are unique in that they are looped and are able to differentiate between mature miRNA sequences that may differ by only a single nucleotide. Also, this assay is specific for mature rather than pre-miRNA molecules. This is important because premiRNA expression levels do not always coincide with mature miRNA levels (Sawera et al. 2005). Because miRNAs are only functional at the mature stage, quantification of expression levels of mature miRNAs is preferred over pre-miRNAs. TaqMan® assays 


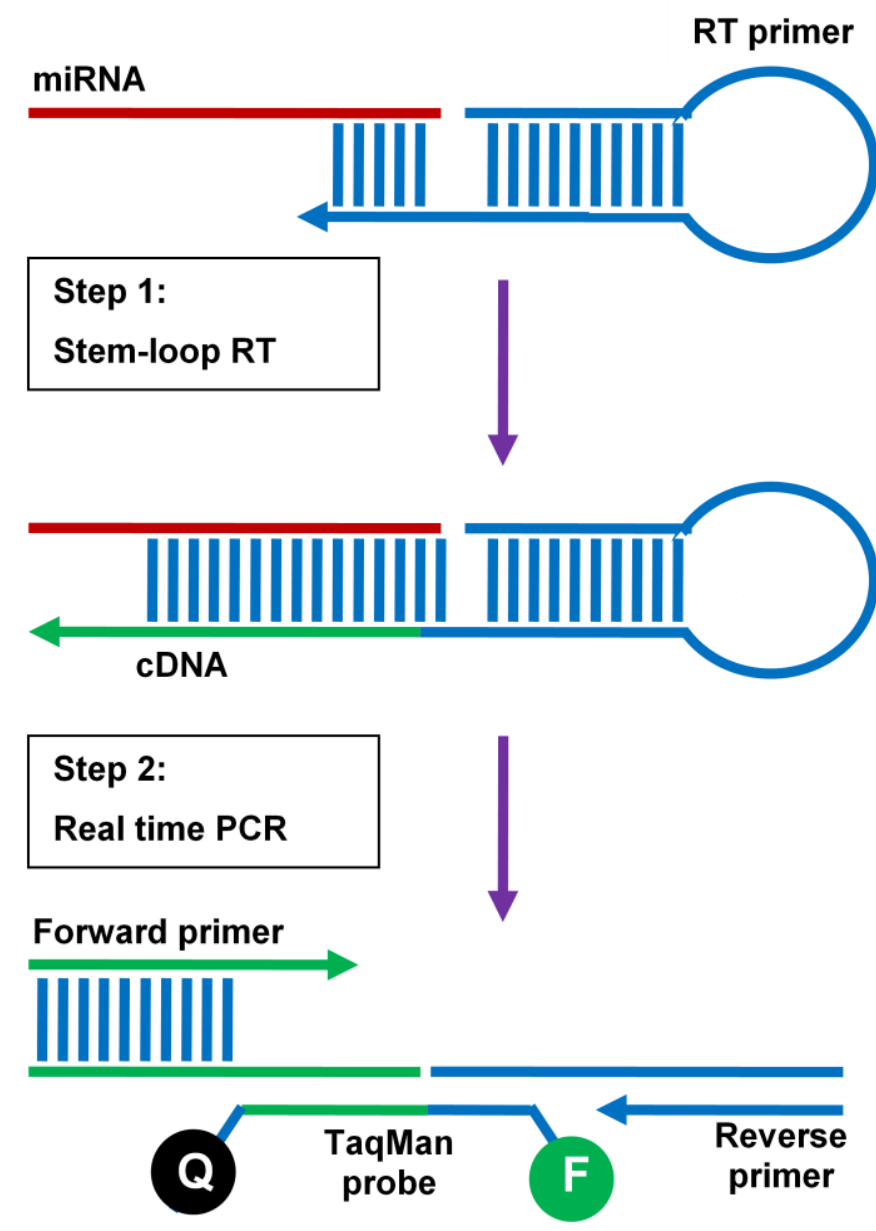

Figure 3. Stem-loop RT-PCR. TaqMan® MicroRNA Assays used novel stem-loop primers designed by Applied Biosystems for the amplification of hundreds of miRNAs from several species. The assays utilized the pathway shown above in order to amplify only the mature miRNA products with a probe specific enough to differentiate miRNAs that may only differ by one nucleotide (Chen et al. 2005). 
also use qRT-PCR. Real time experiments require less RNA input than traditional northern blots, and they can detect RNA transcripts present at extremely low levels. The specificity and sensitivity of this approach made it the ideal candidate for investigation of canine miRNA expression. Validation of the TaqMan® assays for use with the canine system was necessary before relative expression levels could be determined.

Dilution curves with canine RNA were used to determine the specificity and sensitivity of the miRNA assays originally designed for the human. Each primer and probe set for the miR-17-92 cluster and the RNU6B small RNA were tested with total RNA isolated from canine lung. The RNA input ranged five logs (300 ng-0.03 ng). Data showed that the critical threshold $\left(\mathrm{C}_{\mathrm{T}}\right)$ value decreased as the amount of RNA input increased, which is expected for primer and probe assays that are sensitive. The graph depicted in Figure 4 demonstrates that the relationship between RNA input and $\mathrm{C}_{\mathrm{T}}$ is linear and direct. Table 6 compares the correlation values $\left(\mathrm{R}^{2}\right)$ of each assay over four and five orders of magnitude. While some sensitivity was lost when $300 \mathrm{ng}$ of RNA were used, correlation values still remained close to one, thereby confirming the sensitivity of the assays' ability to quantify canine miRNA expression over a dynamic range of RNA input. Real time products from all seven genes and the control were subcloned and verified by sequencing. Taken together, these data indicate that the TaqMan® assay is suitable for investigation of canine miRNA expression. 


\section{Dilution series}

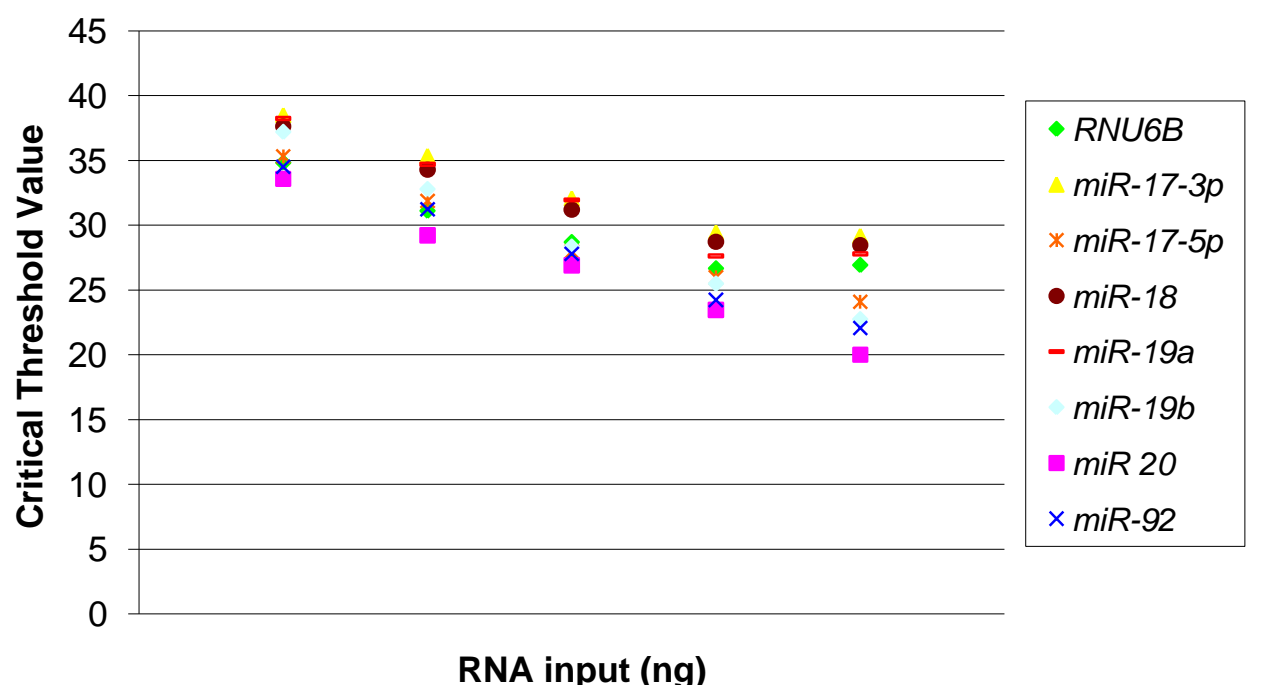

Figure 4. Standard Dilution Curves. Human TaqMan® ${ }^{\circledR}$ miRNA assays were validated for sensitivity using canine RNA.

Table 6. Correlation Values for the miR-17-92 Cluster.

\begin{tabular}{|l|c|c|}
\hline & $\begin{array}{c}\mathbf{R}^{2} \text { values } \\
\text { 4 orders of magnitude } \\
(\mathbf{0 . 0 3 n g - 3 0 n g})\end{array}$ & $\begin{array}{c}\mathbf{R}^{2} \text { values } \\
\text { 5 orders of magnitude } \\
(\mathbf{0 . 0 3} \text { ng-300ng) }\end{array}$ \\
\hline RNU6B control & 0.9797 & 0.8882 \\
\hline miR-17-3p & 0.9979 & 0.9442 \\
\hline miR-17-5p & 0.9845 & 0.9746 \\
\hline$m i R-18$ & 0.9954 & 0.9390 \\
\hline$m i R-19 a$ & 0.9927 & 0.9415 \\
\hline$m i R-19 b$ & 0.9907 & 0.9859 \\
\hline$m i R-20$ & 0.9870 & 0.9935 \\
\hline$m i R-92$ & 0.9996 & 0.9943 \\
\hline
\end{tabular}




\section{Quantification of miRNA Expression}

Having validated use of the miRNA TaqMan® assays, a tissue-specific evaluation of the expression of the miR-17-92 cluster was performed using canine heart, brain, lung, liver, renal cortex, and renal medulla tissues. In addition to confirming the presence of individual miRNAs, the real time approach proved quite suitable for quantifying the relative expression levels of $m i R-17-92$. These data are displayed in Figure 5.

The overall expression of canine $m i R-17-3 p$ and $17-5 p$ is relatively low as compared to other genes in this cluster. For these genes, the highest expression was in the renal medulla and the lowest expression in the liver. Because the levels of mature miRs-17-3p and 17-5p are relatively low in mammalian tissues, they are often unable to be quantified by northern blotting (Hayashita et al. 2005; Sawera et al. 2005); however, the presence of $m i R-17-5 p$ has been detected in murine lung, brain, heart, and kidney using cloning techniques (Sempere et al. 2004). The previous difficulties in studying expression of these two genes highlight the need for a better detection method.

Therefore, the real time approach used in this study will be a useful tool in subsequent investigations.

The highest relative expression of canine $m i R-18$ was in the renal cortex, followed by the lung. Expression was negligible for other tissues analyzed. Likewise, the murine form of $m i R-18$ has been detected in both lung and total kidney (Sempere et al. 2004). In addition, northern blotting revealed expression of $m i R-18$ in porcine kidney and brain (Sawera et al. 2005). 

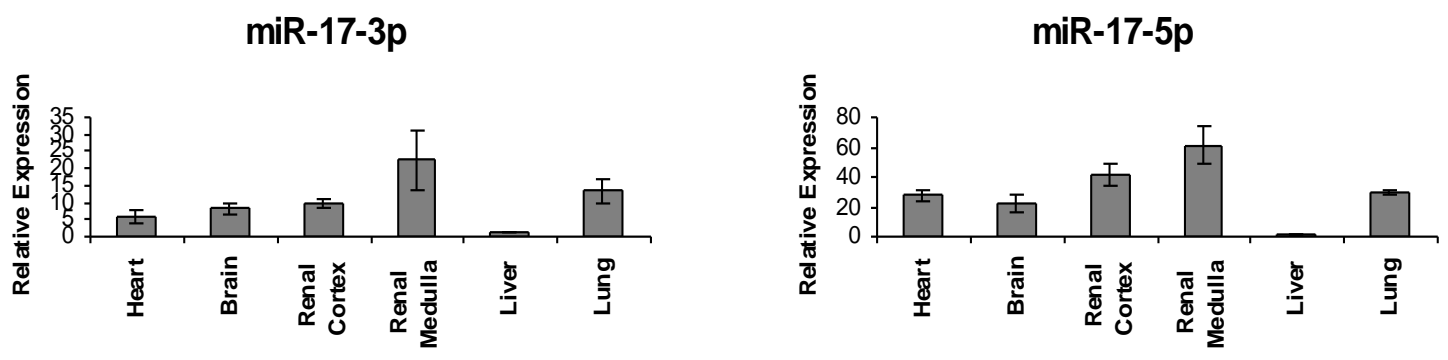

$\operatorname{miR}-18$
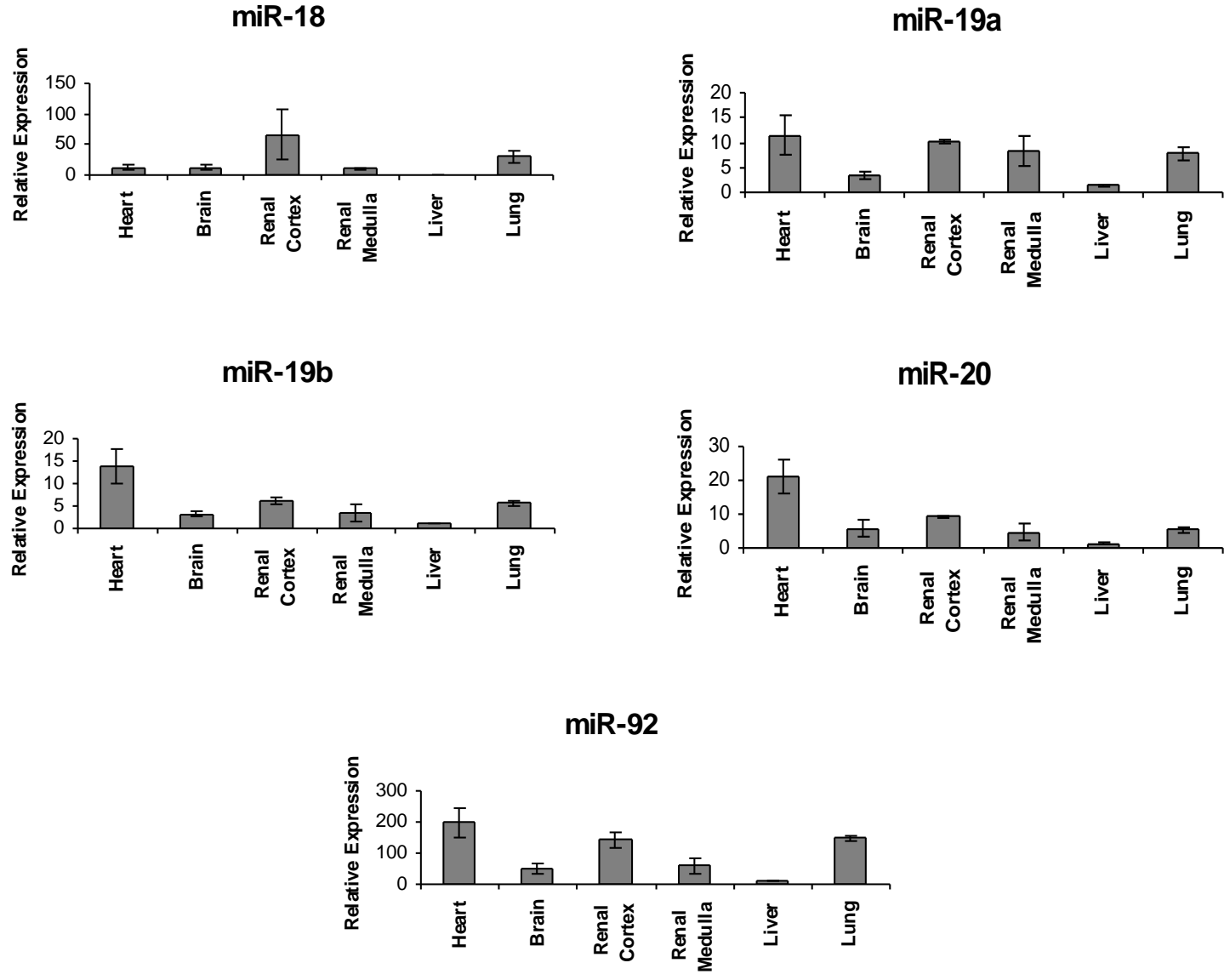

Figure 5. miR-17-92 Expression. Canine expression of the cluster was quantified in six tissues (brain, heart, lung, liver, kidney cortex, and kidney medulla) using qRT-PCR. Expression of the seven miRNAs in the $m i R-17-92$ cluster were individually analyzed using the delta, delta $\mathrm{Ct}$ method of comparison. 
The profiles of $m i R s-19 a$ and $19 b$ followed the same general trends when compared among the six canine tissues: the highest and lowest relative expression levels were found in the heart and liver, respectively. Previous experiments done using northern blotting were unable to distinguish between mirs-19a and $19 b$, because the mature sequences differ by a single nucleotide (Lagos-Quintana et al. 2001). The real time primers and probes used in the current experiments allowed discrimination between the two miRNAs as demonstrated by sequencing. Although northern blotting cannot differentiate between the two genes, mir-19a has been cloned from murine lung as well as the human brain, heart, and liver (Sempere et al. 2004). In addition, miR-19b was cloned from murine lung, brain, liver, heart, and kidney (Sempere et al. 2004).

The expression of canine $m i R-20$ is highest in the heart and lowest in the liver as compared to the other tissue samples. Overall, the trend was heart $>$ renal cortex $>$ brain $>$ lung/renal > medulla > liver. A murine expression profile of mir-20 has been previously generated by use of TaqMan ${ }^{\circledR}$ real time assays. Chen and colleagues (2005) demonstrated that mir-20 mature expression was highest in the lung, followed by the heart, liver, and brain (the kidney was not studied). Although a quantitative approach was taken by them and also in the work reported here, it is difficult to make comparisons between the dog and mouse due to the limited number of samples used in both studies. Detection of $m i R-20$ has also been reported from human lung and murine kidney and lung (Sempere et al. 2004).

Overall expression of canine $m i R-92$ was very dynamic with relative fold changes ranging from 10 to over 200 , as seen in the liver and heart, respectively. 
Although northern blotting is not the ideal method to quantify expression levels, Sawera et al. showed that the mature form of porcine $m i R-92$ is highly expressed in the liver as compared to the kidney and brain. Work with murine lung, heart, and kidney was able to produce clones of this gene (Sempere et al. 2004).

\section{Conclusions}

It is interesting to note that reports assessing renal miRNAs identified the tissue of origin as "kidney" but did not indicate whether the sample was from the renal medulla or the renal cortex. The work reported here shows that within an organ, such as the kidney, the miRNA expression profiles do differ among the different cell populations. Therefore, because other reports do not identify the cellular origins of samples, direct conclusions and comparisons cannot be made.

Provided here is a summary of data collected for different species with regards to the mir-17-92 cluster. These data cannot be directly compared among species because of differences in techniques and the limited number of samples used. Comparing expression levels of individual miRNAs across species will allow for identification of species-specific differences and, perhaps, provide insight into miRNA function at the comparative genomic level. As additional data is published using the real time approach, making these comparisons will be possible.

We have shown the sensitivity and specificity of TaqMan® assays using canine samples, thereby validating use of this approach. Initial expression profiles of the mir17-92 cluster were generated for several canine tissues. As previously mentioned, six 
canine miRNAs have been identified through computational methods; however, this is the first study to demonstrate that canine miRNAs are actually expressed. It is important to note that, although initial observations regarding relative expression levels were made, more samples from a number of different dogs must be included to create true baseline profiles for normal expression. The establishment of a tool to study miRNA expression in the canine system will also allow for future expression studies to evaluate miRNA genes that have been associated with cancer and other diseases. 


\section{CHAPTER IV}

\section{CANINE MAMMARY ONCOMIR STUDY}

\section{Introduction}

The domestic dog may provide the ideal model for oncomir research. Due to the fact that mammary cancer is a spontaneously occurring disease in the domestic dog (as opposed to the often used induced rodent models or manipulated in vitro models), the functional genetics can be more accurately explored. The genetic similarities found between the two species could also mean a conservation of function in that miRNAs may be targeting genes conserved between the human and canine genomes to initiate tumorigenesis or progress metastasis. Previous researchers have shown links between ten miRNAs and breast cancer (summarized in Table 7). This study takes the first step in the canine avenue by identifying the expression levels of oncomirs in canine mammary cancer using the highly sensitive qRT-PCR approach.

\section{Results}

Bioinformatic data revealed the ten oncomirs of interest ( $m i R-15 a, m i R-16, m i R$ 17-5p, miR-21, miR-29b, miR-125b, miR-145, miR-155, miR-181b, let-7f) to have substantial sequence identity between the human and dog at the precursor level and complete conservation at the mature level. Sequence identity is detailed in Table 8. Based upon previous research, the identity found at the mature level permits the use of the ABI TaqMan® MicroRNA assays with canine input despite being designed for the 
Table 7. miRNA Research in Mammary Cancer.

\begin{tabular}{|c|c|c|c|c|c|}
\hline miRNA name & Human & Cancer Source & Function & Analysis Method & References* \\
\hline$m i R-15 a$ & $\begin{array}{l}13 \mathrm{q} 14 \\
\text { (intron } 4 \text { of } \\
D L E U 2 \text { ) }\end{array}$ & $\begin{array}{l}\text { Primary tumors } \\
\text { Cell lines }\end{array}$ & $\begin{array}{l}\text { Tumor } \\
\text { Suppressor }\end{array}$ & $\begin{array}{l}\text { Microarray } \\
\text { aCGH }\end{array}$ & $1,2,3$ \\
\hline$m i R-16$ & $\begin{array}{l}13 \mathrm{q} 14 \\
\text { (intron } 4 \text { of } \\
D L E U 2 \text { ) }\end{array}$ & $\begin{array}{l}\text { Primary tumors } \\
\text { Cell lines }\end{array}$ & $\begin{array}{l}\text { Tumor } \\
\text { Suppressor }\end{array}$ & $\begin{array}{l}\text { Microarray } \\
\text { aCGH }\end{array}$ & $1,2,3$ \\
\hline$m i R-17-5 p$ & $\begin{array}{l}13 \mathrm{q} 31 \\
\text { (intron } 3 \text { of } \\
\text { C13orf 25) }\end{array}$ & $\begin{array}{l}\text { Primary tumors } \\
\text { Cell lines }\end{array}$ & $\begin{array}{l}\text { Tumor } \\
\text { Suppressor/ } \\
\text { Oncogene }\end{array}$ & $\begin{array}{l}\text { Microarray } \\
\text { aCGH }\end{array}$ & $1,2,3,4,5$ \\
\hline$m i R-21$ & $\begin{array}{l}7 \mathrm{q} 23 \\
(3 ’ \mathrm{UTR} \\
V M P 1)\end{array}$ & $\begin{array}{l}\text { Primary tumors } \\
\text { Cell lines }\end{array}$ & Oncogene & $\begin{array}{l}\text { Microarray } \\
\text { Northern Blotting } \\
\text { aCGH }\end{array}$ & $2,3,5,6$ \\
\hline$m i R-29 b$ & $\begin{array}{l}\text { 7q32 \& } \\
\text { 1q32 } \\
\text { (intergenic) }\end{array}$ & $\begin{array}{l}\text { Primary tumors } \\
\text { Cell lines }\end{array}$ & Oncogene & $\begin{array}{l}\text { Microarray } \\
\text { aCGH }\end{array}$ & $2,3,5$ \\
\hline$m i R-125 b$ & $\begin{array}{l}11 \mathrm{q} 24 \\
\text { (intergenic) } \\
\& 21 \mathrm{q} 1 \text { (intron } \\
\text { of } C 21 \text { orf } 34 \text { ) }\end{array}$ & $\begin{array}{l}\text { Primary tumors } \\
\text { Cell lines }\end{array}$ & $\begin{array}{l}\text { Tumor } \\
\text { Suppressor }\end{array}$ & $\begin{array}{l}\text { Microarray } \\
\text { Northern Blotting } \\
\text { aCGH }\end{array}$ & $2,3,7$ \\
\hline$m i R-145$ & $\begin{array}{l}5 \mathrm{q} 32 \\
\text { (intergenic) }\end{array}$ & $\begin{array}{l}\text { Primary tumors } \\
\text { Cell lines }\end{array}$ & $\begin{array}{l}\text { Tumor } \\
\text { Suppressor }\end{array}$ & $\begin{array}{l}\text { Microarray } \\
\text { Northern Blotting }\end{array}$ & 2 \\
\hline$m i R-155$ & $\begin{array}{l}21 \mathrm{q} 21.3 \\
\text { (exon } 3 \text { of } \\
\text { ncRNA } B I C \text { ) }\end{array}$ & $\begin{array}{l}\text { Primary tumors } \\
\text { Cell lines }\end{array}$ & Oncogene & Microarray & 2,5 \\
\hline$m i R-181 b$ & $\begin{array}{l}\text { 9q33.3 } \\
\text { (intergenic) }\end{array}$ & Primary tumors & $\begin{array}{l}\text { Tumor } \\
\text { Suppressor/ } \\
\text { Oncogene }\end{array}$ & $\begin{array}{l}\text { Microarray } \\
\text { aCGH }\end{array}$ & 3,5 \\
\hline let-7f & $\begin{array}{l}\text { Several } \\
\text { sites }\end{array}$ & $\begin{array}{l}\text { Primary tumors } \\
\text { Cell lines }\end{array}$ & $\begin{array}{l}\text { Tumor } \\
\text { Suppressor }\end{array}$ & $\begin{array}{l}\text { Microarray } \\
\text { qRT-PCR }\end{array}$ & $2,6,7$ \\
\hline
\end{tabular}

*References: 1: (Calin and Croce 2006b); 2: (Iorio et al. 2005); 3: (Zhang et al. 2006); 4: (Hossain et al. 2006); 5: (Volinia et al. 2006); 6: (Jiang et al. 2005); 7: (Mattie et al. 2006) 
corresponding miRNA genes of the human (Boggs et al. 2007). qRT-PCR was chosen as the method of choice to quantify miRNA expression due to its need for very little RNA input as well as the specificity and sensitivity of TaqMan®.

Table 8. Mammary Oncomir Conservation Comparison.

\begin{tabular}{|l|c|c|c|c|}
\hline miRNA & $\begin{array}{c}\text { Human } \\
\text { location }\end{array}$ & $\begin{array}{c}\text { Canine } \\
\text { location }\end{array}$ & $\begin{array}{c}\text { Precursor } \\
\text { Identity (\%) }\end{array}$ & $\begin{array}{c}\text { Mature } \\
\text { Identity (\%) }\end{array}$ \\
\hline let-7f & $9 / \mathrm{X}$ & $1 / \mathrm{X}$ & 100 & 100 \\
\hline$m i R-15 a$ & 13 & 22 & 100 & 100 \\
\hline$m i R-16$ & 13 & 22 & 97.5 & 100 \\
\hline$m i R-17-5 p$ & 13 & 22 & 100 & 100 \\
\hline$m i R-21$ & 17 & 9 & 99 & 100 \\
\hline$m i R-29 b$ & $7 / 1$ & $14 / 7$ & 100 & 100 \\
\hline$m i R-125 b$ & 11 & 5 & 98 & 100 \\
\hline$m i R-145$ & 5 & 4 & 94 & 100 \\
\hline$m i R-155$ & 21 & 31 & 94.5 & 100 \\
\hline$m i R-181 b$ & 1 & 7 & 95.5 & 100 \\
\hline
\end{tabular}

A brief comparison (see Figure 6) of the overall expression of the ten miRNAs studied with qRT-PCR and analyzed with the traditional delta, delta Ct method, reveals five miRNAs with tumor suppressor activities ( $m i R s-15 a, 16,17-5 p, 125 b$ and 155) and four with oncogenic activity ( $m i R s-21,29 b, 181 b$, and let-7f). MiR-145 does not seem to differ in expression between normal and malignant mammary tissues. The statistical analysis to compute p-values (listed in Table 9) was performed using the Multivariate Analysis of Variance (MANOVA) calculation, a more robust test than the standard ttest. MANOVA takes into account that all ten miRNAs were evaluated on the same six samples, and it revealed $m i R-21$ and $m i R-29 b$ to be significantly different $(\mathrm{p} \leq .05)$. 


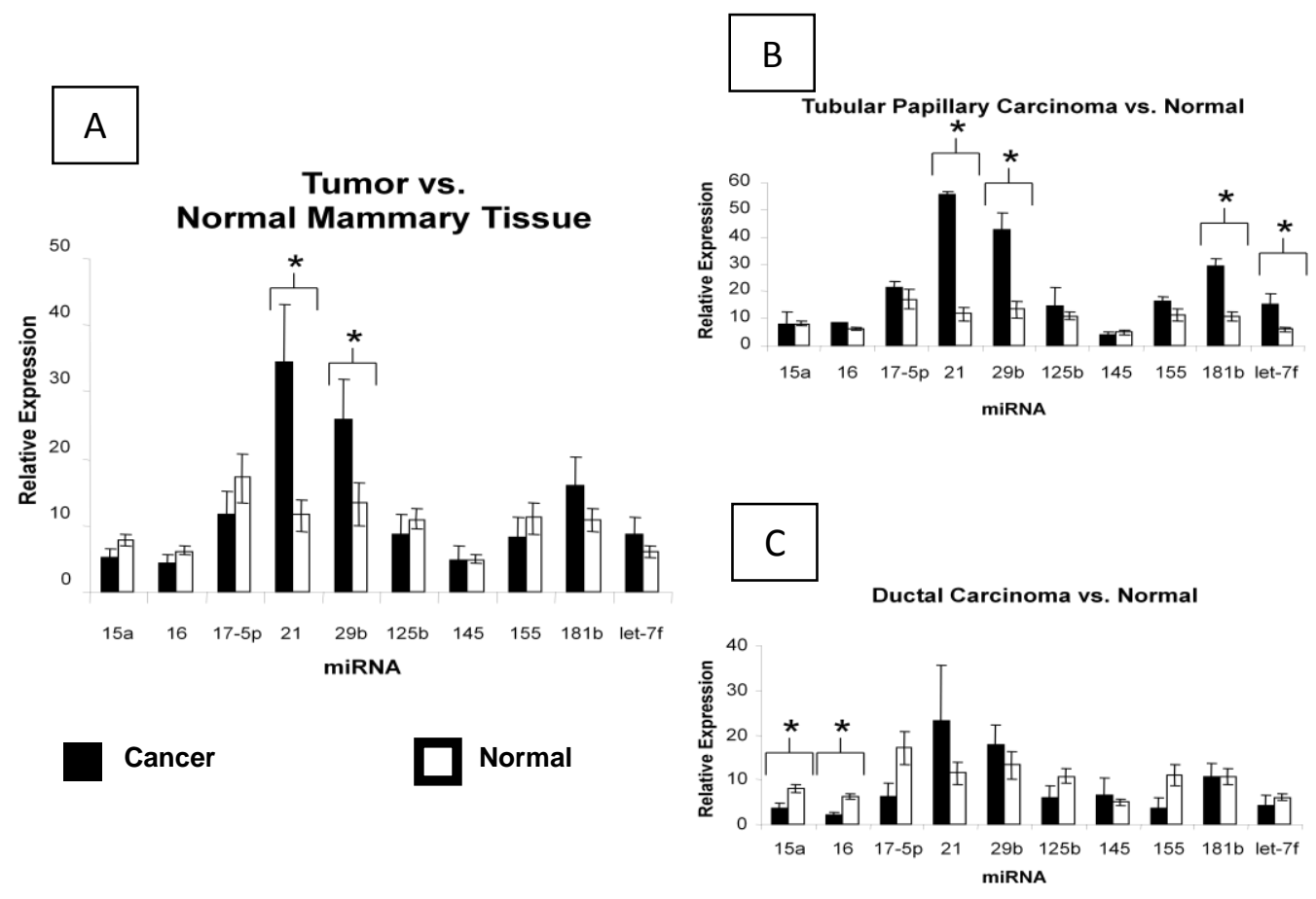

Figure 6. Mammary Oncomir Expression. Expression levels of 10 oncomirs were studied from normal and cancerous canine breast tissue and compared using a MANOVA analysis. A. Compares all six tumor samples versus ten normal samples. B. Compares two tubular papillary carcinoma samples to the ten normals. C. Compares three ductal carcinoma samples to the ten normal samples. 
Table 9. P-values for Total and Subtype Analysis. P-values are listed for each miRNA and were calculated using MANOVA.

Normal Mammary Tissue vs. All Cancer Samples

\begin{tabular}{ll}
\hline miR $15 a$ & 0.09 \\
miR 16 & 0.16 \\
miR $17-5 p$ & 0.34 \\
miR 21 & $0.01^{*}$ \\
miR $29 b$ & $0.05^{*}$ \\
miR $125 b$ & 0.46 \\
miR 145 & 0.99 \\
miR 155 & 0.48 \\
miR $181 b$ & 0.23 \\
let-7f & 0.30
\end{tabular}

Normal Mammary Tissue vs. Ductal Carcinomas

$\begin{array}{ll}\text { miR } 15 a & 0.98 \\ \text { miR } 16 & 0.19 \\ \text { miR } 17-5 p & 0.61 \\ \text { miR } 21 & 0.000019^{*} \\ \text { miR } 29 b & 0.003^{*} \\ \text { miR } 125 b & 0.36 \\ \text { miR } 145 & 0.59 \\ \text { miR } 155 & 0.38 \\ \text { miR } 181 b & 0.002^{*} \\ \text { let-7f } & 0.002^{*}\end{array}$

Normal Mammary Tissue vs. Tubular Papillary Carcinomas

$\begin{array}{ll}\text { miR } 15 a & 0.024^{*} \\ \text { miR } 16 & 0.009 * \\ \text { miR } 17-5 p & 0.145 \\ \text { miR } 21 & 0.158 \\ \text { miR } 29 b & 0.492 \\ \text { miR } 125 b & 0.154 \\ \text { miR } 145 & 0.504 \\ \text { miR } 155 & 0.129 \\ \text { miR } 181 b & 0.977 \\ \text { let- } 7 f & 0.337\end{array}$


However, the biological trends cannot be ignored and will be further addressed in the discussion.

Further analysis compared the samples based upon two types of histology (ductal carcinomas and tubular papillary carcinomas) revealing $m i R-15 b$ and $m i R-16$ to have a significantly lower expression in canine ductal carcinoma diagnoses versus normal samples. The ductal carcinomas were identified by neoplastic cells invading the mammary gland. Alternatively, tubular papillary carcinomas invaded the mammary glands, producing abnormal tubular projections into the duct. The tubular papillary tumors had a higher expression of let- $7 f$ and $m i R-181$. This is in addition to $m i R-21$ and $m i R-29 b$, and indicates that these four genes may have oncogenic roles in this particular type of malignancy.

\section{Discussion}

It was not surprising to find the oncomirs of interest are highly conserved between the canine and human. Previous analysis of the two species has revealed that the canine sequence, as a whole, shows great sequence identity to the human, even more than the popular murine model (Kirkness et al. 2003). The physiology of the dog enables larger and easier to obtain specimen collections as compared to rodent models. The companion animals also have extraordinary health care, second only to that of the human medicine. The vast similarities in both genetics and physiology and considerable overlap in treatment regimens make the domestic dog an ideal model for many human diseases, including malignant mammary cancer. 
Like the human, the domestic dog is known to have several risk factors for the development of mammary cancer. All canine mammary tumors appear to be promoted by sex hormones (Lana et al. 2007). Studies have shown that there is a direct correlation between the total amount of estrogen exposure and the risk for mammary tumor development. Dogs that are spayed before their first, second, or third estrus cycle have a risk of $0.5 \%, 8 \%$, and $26 \%$ respectively for developing a mammary tumor(Schneider et al. 1969). This is similar to human research that has shown that early aged menopausal women have a significant decrease in risk for development of mammary cancer compared to those women who reach menopause at biologically normal times (Dickson et al. 2005).

It must be noted that what is known about the role of estrogen receptors in canine mammary tumors indicates that they may not be good biologic models of human mammary cancer. That is, while estrogen clearly promotes the growth of breast cancer in both species (Dickson et al. 2005; Schneider et al. 1969), multiple studies have shown that in true canine mammary malignancies, estrogen receptors are down-regulated compared to normal mammary tissue (Illera et al. 2006; Millanta et al. 2005; Nieto et al. 2000). This finding is markedly different when compared to the majority of human post menopausal mammary cancer (Dickson et al. 2005). Consequently, estrogen receptors blockers such as tamoxifen have little effect in the dog. Interestingly, dysplasia and benign canine tumors have elevations in the estrogen receptors similar to women. Thus, the potential of dogs with mammary tumors to serve as models for study of human mammary cancers is not without complication. Even so, the conflicting data pertaining 
to estrogen receptors is outweighed by the aforementioned shared characteristics between canine and human mammary cancers. These similarities suggest that while treatment response may vary due to the lack of estrogen receptors, the biologic development and progression of mammary cancers in these two species is similar enough to enhance the understanding of human mammary cancer through the use of the canine model. To this end, evaluation of miRNAs in canine mammary tissue may be a highly productive avenue of investigation.

Previous work grouped oncomirs into three categories: tumor suppressors, oncogenes, and those that fulfill both functions (Calin and Croce 2006a; EsquelaKerscher and Slack 2006; Wijnhoven et al. 2007; Zhang et al. 2007). Because miRNAs can bind to more than one mRNA (see Figure 2), it is not only possible, but more than likely, that they will bind to several mRNAs. Likewise, the miRNAs studied in this manuscript can be placed into one of the three categories.

\section{Tumor Suppressors}

The first oncomirs, $m i R s-15 a$ and 16 , were initially discovered to play a role in chronic B-cell lymphocytic leukemia (Calin et al. 2004a). They are clustered together at a known cancer fragile site and act to suppress tumors by reppressing BCL2, an antiapoptotic oncogene (Cimmino et al. 2005). The loss of these two miRNAs results in overexpression of $B C L 2$ and subsequent pro-survival states, a documented event in the majority of chronic cases of B-cell lymphocytic leukemia cases (Cimmino et al. 2005). Decreased expression and a loss in copy number of $m i R-15 a$ and $m i R-16$ were found in other hematopoetic and solid cancers, including human mammary cancers (Bottoni et al. 
2005; Iorio et al. 2005; Mattie et al. 2006; Volinia et al. 2006). The work reported here provides evidence that both $m i R-15 a$ and $m i R-16$ are generally suppressed in canine mammary carcinomas. However, when the ductal carcinoma phenotype is singled out, the different patterns of expression become significant. It is thus reasonable to hypothesize that $m i R-15 a$ and $m i R-16$ may be responsible for the differentiation of the malignancy.

Another known tumor suppressor, $m i R-125 b$, also acts to control cell proliferation, and regulates the oncogene Lin28 in the human (Lee et al. 2005; Wu and Belasco 2005). Expression of this miRNA in the dog is reduced in malignant samples as compared to normal mammary tissues. This is in agreement with microarray, northern blotting and comparative genomic hybridization studies done on primary and in vitro samples from the human (Blenkiron et al. 2007; Iorio et al. 2005; Mattie et al. 2006; Volinia et al. 2006; Zhang et al. 2006).

Differential expression of $m i R-145$ was not detected in canine mammary cancer, but it is described as a tumor suppressor and has been found to target FLJ21308 in the human (Kiriakidou et al. 2004). This oncomir is more often associated with colorectal tumors (Bandres et al. 2006), but studies have documented a differential expression in mammary cancer (Iorio et al. 2005; Volinia et al. 2006). It is interesting to note that one group described the expression of both the mature and precursor expression levels of miR-145 in colorectal tumors, but only found a difference at the mature level (Michael et al. 2003). This finding underscores the importance of choosing expression tools that target the "functional element" of miRNAs, i.e. the mature product. 


\section{Oncogenes}

The oncogenes, $m i R-21$ and $m i R-29 b$ are associated with numerous cancers, including human mammary cancer (Blenkiron et al. 2007; Esquela-Kerscher and Slack 2006; Fabbri et al. 2007; Frankel et al. 2007; Iorio et al. 2005; Mattie et al. 2006; Meng et al. 2007; Mott et al. 2007; Pekarsky et al. 2006; Si et al. 2007; Silveri et al. 2006; Volinia et al. 2006; Zhang et al. 2006; Zhu et al. 2007). Consistently, these two miRNAs are up-regulated in analyses of mammary cancers using microarrays, and Zhang and colleagues confirmed that these two oncogenes showed an increase in copy number in mammary tumor tissues (2006). In particular, miR-21 targets both PTEN and TPM1, and the loss of this miRNA results in increased caspase activity and subsequent apoptosis (Meng et al. 2007; Zhu et al. 2007). Tcll and MCL1 are targets of miR-29b (Mott et al. 2007; Pekarsky et al. 2006). Because these miRNAs have roles in so many cancers, it is reasonable to hypothesize that they have a role in general role in tumorigenesis rather than a specific role in metastasis or development of mammary cancers. Both miRNAs were significantly up-regulated in tumors for this study $(\mathrm{p} \leq .05)$. They remained significant even when the tubular papillary carcinoma phenotype was separately analyzed. Because of the increased expression, $m i R-21$ and $m i R-29 b$ may be ideal targets for in vitro knockdown studies. By targeting the supposed oncogenic activity, perhaps tumor growth could be slowed or halted altogether.

\section{Combination Tumor Suppressors and Oncogenes}

Some miRNAs serve opposing roles, specifically as both tumor suppressor and oncogenes. This is the most interesting and complicated category of miRNAs, and as 
functional studies continue and more data are generated, it is likely that many more oncomirs will be found to have these dual roles.

Known to suppress the oncogene $A I B 1, m i R-17-5 p$ would be classified in the tumor suppressor category (Hossain et al. 2006). However, it is also known to target E2F1, the transcription factor for $c-M y c$ (Hossain et al. 2006; O'Donnell et al. 2005). Previous work showed overexpression of $m i R-17-5 p$ in several cancers, and this miRNA is known to specifically accelerate C-MYC-induced tumorigenesis in the mouse (He et al. 2005). Both Iorio et.al. (2005) and Volina et.al. (2006) used microarray data to suggest that $m i R-17-5 p$ acts as an oncogene in mammary cancers while multiple other studies used a variety of techniques to show evidence of $m i R-17-5 p$ acting as tumor suppressor (Hossain et al. 2006; Lu et al. 2005; O'Donnell et al. 2005; Zhang et al. 2006). In fact, this miRNA is deleted, due to its fragile site position, in $21.9 \%$ of breast cancer samples (Zhang et al. 2006). The data from the dog correlate with the majority of the findings when all mammary tumors and when tubular papillary carcinomas were analyzed. There does not seem to be a difference in expression in the ductal carcinomas. Because the differences were not statistically significant, additional tumor samples would need to be collected to further investigate the role of $m i R-17-5 p$ in canine mammary cancer.

In chronic lymphocytic leukemia, $m i R-181 b$ targets $T c l 1$, another known oncogene, suggesting that the miRNA is a tumor suppressor (Pekarsky et al. 2006). Other work implicated the gene in differentiation of B-cells (Chen and Lodish 2005). In human glioblastoma and pituitary adenomas, $m i R-181 \mathrm{~b}$ seems to act in a tumor 
suppression fashion (Bottoni et al. 2007; Ciafre et al. 2005). However, Zhang et.al. (2006) convincingly reported an increased copy number of $m i R-181 b$ in mammary tumors, and microarray studies showed overexpression of this miRNA in mammary cancer tissue samples (2006). Overall, the canine mammary tumors appear to over express $m i R-181 b$. In the tubular papillary carcinomas, the miRNA is significantly overexpressed, indicating that $m i R-181 \mathrm{~b}$ may be an important in differentiation of mammary cells as well.

Located within the $B I C$ gene, $m i R-155$ is generally thought of as an oncogene, because it is overexpressed in heamopoeitic cancers, thyroid cancers and lung adenocarcinomas (Costinean et al. 2006; Mattie et al. 2006; Volinia et al. 2006; Zhang et al. 2006). Microarray data showed an increase in expression in multiple tumor samples of different origins giving further evidence for this oncogenic role (Iorio et al. 2005; Volinia et al. 2006). However, a study on pancreatic cancer showed $m i R-155$ to be down-regulated (Roldo et al. 2006). In canine mammary cancers, the miRNA takes on both roles, dependent upon tumor differentiation. The average expression in tubular papillary carcinomas is lower compared to normal mammary tissue, while the ductal carcinomas display a slightly higher expression when compared to the healthy counterparts. It is important to note that only the averages are being compared, because the difference of expression was not considered statistically significant. Interestingly, Mattie and colleagues found that $m i R-155$ is differentially expressed when comparing estrogen receptor positive and negative tumors (2006). 
A part of the let-7 family of miRNAs, let-7f is described as a tumor suppressor because it knocks down the oncogene, ras (Johnson et al. 2005). The let-7f miRNA is conserved in as distantly related species as the worm, plant, and fruitfly (Pasquinelli et al. 2000). By targeting $K$-ras and $N$-ras mRNA for degradation, let-7f's role in cancer cell proliferation was clear (Johnson et al. 2007). In addition, multiple studies have shown a reduced expression of this miRNA in lung cancer (Jiang et al. 2005; Johnson et al. 2007; Johnson et al. 2005). However, one study used the highly sensitive qRT-PCR and showed an up- regulation of let-7f in breast cancer cell lines (Jiang et al. 2005). Only the tubular papillary carcinomas of canine mammary cancer showed a statistically significant increase in expression of let-7f, and supports the findings of the qRT-PCR study.

The data collected in this study were generated using a qRT-PCR approach that has proven specificity and sensitivity. This technique is vital when there is very little RNA obtained from the mammary biopsies and the miRNAs being quantified only differ by one nucleotide. While northern blots were not performed to confirm the data, previous research has shown the qRT-PCR approach to be more accurate. In addition, the RNU6B assay was chosen as the "housekeeping gene" for two reasons: previous researchers have used the U6 control, making the data comparable, and the expression of RNU6B was found to be relatively consisted among several cancers (Jiang et al. 2005).

Relatively few samples were used in this study due to the difficulty in obtaining tumor and normal tissue from client owned animals. This means that while most of the miRNAs did not show statistically significant differences, they still may play vital roles 
in cancer. The analysis of more tumor samples to improve the power of the study is required before any definitive statements on the role of miRNAs in canine mammary cancer are made. This point underscores the need for future collaborations between veterinarians and researchers as well as the establishment of tumor banks.

The fact that the domestic dog appears shares characteristics with human breast cancers as described in copious literature is encouraging as it provides theory for future research that utilizes the dog as a breast cancer model. As more samples are collected and in vitro cell lines are established, more canine phenotypes can be explored and compared to the human forms of malignancy beyond just breast cancer. The cell type specific actions should be further investigated and predicted targets can be tested in cell lines derived from canine tumor samples. Elucidating the actions of miRNAs will advance cancer diagnostics, treatment and survival by providing gene therapy targets of the future. Ideally, the miRNAs found to be involved in tumorigenesis or tumor suppression could serve as targets for gene therapy in both the dog and the human. 


\section{CHAPTER V}

\section{CONCLUSIONS AND FUTURE STUDIES}

The National Institute of Health is now recognizing how valuable comparative studies are by forming the Comparative Oncology Trials Consortia, COTC, which, through14 veterinary schools, perform clinical trials on dogs and cats with cancer. With increased acceptance by researchers, the domestic dog could provide great insight into the future on human breast cancer cures. But the benefit directly to veterinary studies cannot be overlooked. Finding effective treatments for pets suffering from breast cancer could alleviate much pain and cost to today's pet owners, many of which consider their dog a true member of their family.

\section{Summary}

By showing the expression of miRNAs in the dog and specifically in canine mammary cancer, the first steps of canine oncomir research have been set forth. A comparative in silico analysis has been completed identifying close to 300 miRNAs that are conserved between the canine and human genomes. The $m i R-17-92$ cluster and nine additional oncomirs have been investigated by using a verified and sensitive quantifiable approach. The resulting data show that canine miRNA expression is similar to that of the human. Expression is tissue specific, and different subtypes of mammary cancer (tubular papillary carcinomas and ductal carcinomas) show different expression profiles. 


\section{Conclusions and Future Directions}

Simply put, the domestic dog may be an excellent model for the study of human miRNA studies. Research is this field will advance both human and veterinary medicine. Although evaluated in a small number of samples, two oncomirs, $m i R-21$ and $m i R-29 b$, show very significant differences in expression, and both act as oncogenes. These two have also been investigated in the mouse, rat, and human and have been found to act as oncogenes in those species as well. Their high conservation may lead to a therapeutic target for multiple species. Additional samples and future research could identify other targets.

Ideally, canine specific miRNAs could be cloned and sequenced. A microarray analysis could be done on the human miRNA chip that may reveal differences between the canine mammary tumors and normal mammary tissue. With more tumor samples, more robust statistical analysis could be used. Immunochemistry and protein analyses could be initiated to differentiate the subtypes and complement the genetic discoveries. When the tumors are separate by subtypes, profiles can be made like they were in the human. By understanding the profiles we can not only target our veterinary treatments, but also effectively separate the different functional mechanisms that are in place. Now we must dive into the world of canine oncomirs and investigate what their functional roles are and if the roles are conserved in the human as well.

One approach would be to use the targets of these particular miRNAs and compare the targets between humans and dogs. It follows that if the miRNAs function the same in both species they may be targeting the same mRNAs, so these homologous 
mRNAs will probably be highly conserved between species. Ultimately, knockdown and knock-in experiments will need to be performed by using shRNAs and antigomirs to manipulate a specific miRNA. Thus canine normal and tumor mammary cell lines will need to be created from primary tissue in order to evaluate and study miRNAs at work in the canine in vitro model.

The end goal of this research will always be: finding a cure. Genetically modified viruses can be used with in vivo models for gene therapy. Clinical trials could use a therapeutic virus to manipulate the expression of a specific miRNA or multiple miRNAs to control or reduce tumor growth. If successful in the dog, the virus could be modified and further tested in the human. In addition, human RNAi trials are currently being investigated. If success is found in the human area, the therapy could possibly be applied to veterinary medicine as well.

In conclusion, miRNA research is a rapidly expanding field with seemingly endless possibilities. The domestic dog should not be overlooked as science progresses. Its value to human studies is hopefully obvious and will continue to grow as relationships between veterinarians and researchers are formed. With the establishment of tumor banks and the advancement of genetic tools, research will be expedited and improved. By working together the cure can be found. 


\section{REFERENCES}

1. Adams BD, Furneaux H, White BA (2007) The micro-ribonucleic acid (miRNA) miR-206 targets the human estrogen receptor-alpha (ERalpha) and represses ERalpha messenger RNA and protein expression in breast cancer cell lines. Mol Endocrinol 21, $1132-1147$

2. Ahern TE, Bird RC, Bird AE, Wolfe LG (1996) Expression of the oncogene cerbB-2 in canine mammary cancers and tumor-derived cell lines. Am J Vet Res 57, 693696

3. Ambros V (2004) The function of animal microRNAs. Nature 431, 350-355

4. American Cancer Society (2007) Cancer Facts and Figures 2007. Accessed at http://www.cancer.org/downloads/STT/CAFF2007PWSecured.pdf

5. Aravin A, Tuschl T (2005) Identification and characterization of small RNAs involved in RNA silencing. FEBS Letters 579, 5830-5840

6. Bandres E, Cubedo E, Agirre X, Malumbres R, Zarate R, Ramirez N, Abajo A, Navarro A, Moreno I, Monzo M, Garcia-Foncillas J (2006) Identification by Real-time PCR of 13 mature microRNAs differentially expressed in colorectal cancer and nontumoral tissues. Mol Cancer 5, 29

7. Bartel DP (2004) MicroRNAs: Genomics, Biogenesis, Mechanism, and Function. Cell 116, 281-297

8. Benjamin SA, Lee AC, Saunders WJ (1999) Classification and behavior of canine mammary epithelial neoplasms based on life-span observations in beagles. Vet Pathol 36, 423-436

9. Blenkiron C, Goldstein LD, Thorne NP, Spiteri I, Chin SF, Dunning MJ, Barbosa-Morais NL, Teschendorff AE, Green AR, Ellis IO, Tavare S, Caldas C, Miska EA (2007) MicroRNA expression profiling of human breast cancer identifies new markers of tumour subtype. Genome Biol 8, R214

10. Boggs RM, Moody JA, Long CR, Tsai KL, Murphy KE (2007) Identification, amplification and characterization of miR-17-92 from canine tissue. Gene 404, 25-30

11. Bottoni A, Piccin D, Tagliati F, Luchin A, Zatelli MC, degli Uberti EC (2005) miR-15a and miR-16-1 down-regulation in pituitary adenomas. J Cell Physiol 204, 280285 
12. Bottoni A, Zatelli MC, Ferracin M, Tagliati F, Piccin D, Vignali C, Calin GA, Negrini M, Croce CM, Degli Uberti EC (2007) Identification of differentially expressed microRNAs by microarray: a possible role for microRNA genes in pituitary adenomas. $\mathrm{J}$ Cell Physiol 210, 370-377

13. Bourdon JC (2007) p53 and its isoforms in cancer. Br J Cancer 97, 277-282

14. Breen M, Hitte C, Lorentzen TD, Thomas R, Cadieu E, Sabacan L, Scott A, Evanno G, Parker HG, Kirkness EF, Hudson R, Guyon R, Mahairas GG, Gelfenbeyn B, Fraser CM, Andre C, Galibert F, Ostrander EA (2004) An integrated 4249 marker FISH/RH map of the canine genome. BMC Genomics 5, 65

15. Calin GA, Croce CM (2006a) MicroRNA-cancer connection: the beginning of a new tale. Cancer Res 66, 7390-7394

16. Calin GA, Croce CM (2006b) MicroRNA signatures in human cancers. Nat Rev Cancer 6, 857-866

17. Calin GA, Liu CG, Sevignani C, Ferracin M, Felli N, Dumitru CD, Shimizu M, Cimmino A, Zupo S, Dono M, Dell'Aquila ML, Alder H, Rassenti L, Kipps TJ, Bullrich F, Negrini M, Croce CM (2004a) MicroRNA profiling reveals distinct signatures in B cell chronic lymphocytic leukemias. Proc Natl Acad Sci U S A 101, 11755-11760

18. Calin GA, Sevignani C, Dumitru CD, Hyslop T, Noch E, Yendamuri S, Shimizu M, Rattan S, Bullrich F, Negrini M, Croce CM (2004b) Human microRNA genes are frequently located at fragile sites and genomic regions involved in cancers. PNAS 101, 2999-3004

19. Castagnaro M (1995) [Ras gene analysis in mammary tumors of dogs by means of PCR-SSCP and direct genomic analysis]. Ann Ist Super Sanita 31, 337-341

20. Chang SC, Chang CC, Chang TJ, Wong ML (2005) Prognostic factors associated with survival two years after surgery in dogs with malignant mammary tumors: 79 cases (1998-2002). J Am Vet Med Assoc 227, 1625-1629

21. Chen C, Ridson DA, Broomer AJ, Zhou Z, Lee DH, Nguyen JT, Barbisin M, Xu NL, Mahuvakar VR, Andersen MR, Lao KQ, Livak KJ, Guegler KJ (2005) Real-time quantification of microRNAs by stem-loop RT-PCR. Nucleic Acids Research 33, e179

22. Chen CZ, Lodish HF (2005) MicroRNAs as regulators of mammalian hematopoiesis. Semin Immunol 17, 155-165 
23. Chu LL, Rutteman GR, Kong JM, Ghahremani M, Schmeing M, Misdorp W, van Garderen E, Pelletier J (1998) Genomic organization of the canine p53 gene and its mutational status in canine mammary neoplasia. Breast Cancer Res Treat 50, 11-25

24. Ciafre SA, Galardi S, Mangiola A, Ferracin M, Liu CG, Sabatino G, Negrini M, Maira G, Croce CM, Farace MG (2005) Extensive modulation of a set of microRNAs in primary glioblastoma. Biochem Biophys Res Commun 334, 1351-1358

25. Cimmino A, Calin GA, Fabbri M, Iorio MV, Ferracin M, Shimizu M, Wojcik SE, Aqeilan RI, Zupo S, Dono M, Rassenti L, Alder H, Volinia S, Liu CG, Kipps TJ, Negrini M, Croce CM (2005) miR-15 and miR-16 induce apoptosis by targeting BCL2. Proc Natl Acad Sci U S A 102, 13944-13949

26. Costinean S, Zanesi N, Pekarsky Y, Tili E, Volinia S, Heerema N, Croce CM (2006) Pre-B cell proliferation and lymphoblastic leukemia/high-grade lymphoma in E(mu)-miR155 transgenic mice. Proc Natl Acad Sci U S A 103, 7024-7029

27. de Las Mulas JM, Millan Y, Dios R (2005) A prospective analysis of immunohistochemically determined estrogen receptor alpha and progesterone receptor expression and host and tumor factors as predictors of disease-free period in mammary tumors of the dog. Vet Pathol 42, 200-212

28. Dennis C (2006) Cancer: off by a whisker. Nature 442, 739-741

29. Dickson RB, Pestell RG, Lippman ME (2005) Cancer of the breast. In Cancer: Principles and Practice of Oncology 7th ed., DeVita, Hellman, Rosenberg, eds. (Philadelphia: Lippincott Williams \& Wilkins), pp 1399-1488

30. Dobson JM, Samuel S, Milstein H, Rogers K, Wood JL (2002) Canine neoplasia in the UK: estimates of incidence rates from a population of insured dogs. J Small Anim Pract 43, 240-246

31. Donnay I, Rauis J, Devleeschouwer N, Wouters-Ballman P, Leclercq G, Verstegen J (1995) Comparison of estrogen and progesterone receptor expression in normal and tumor mammary tissues from dogs. Am J Vet Res 56, 1188-1194

32. Dore M, Lanthier I, Sirois J (2003) Cyclooxygenase-2 expression in canine mammary tumors. Vet Pathol 40, 207-212

33. Dorn CR, Taylor DO, Frye FL, Hibbard HH (1968) Survey of animal neoplasms in Alameda and Contra Costa Counties, California. I. Methodology and description of cases. J Natl Cancer Inst 40, 295-305 
34. Dutra AP, Granja NV, Schmitt FC, Cassali GD (2004) c-erbB-2 expression and nuclear pleomorphism in canine mammary tumors. Braz J Med Biol Res 37, 1673-1681

35. Egenvall A, Bonnett BN, Ohagen P, Olson P, Hedhammar A, von Euler H (2005) Incidence of and survival after mammary tumors in a population of over 80,000 insured female dogs in Sweden from 1995 to 2002. Prev Vet Med 69, 109-127

36. Elbashir SM, Harborth J, Weber K, Tuschl T (2002) Analysis of gene function in somatic mammalian cells using small interfering RNAs. Methods 26, 199-213

37. Esquela-Kerscher A, Slack FJ (2006) Oncomirs - microRNAs with a role in cancer. Nat Rev Cancer 6, 259-269

38. Fabbri M, Garzon R, Cimmino A, Liu Z, Zanesi N, Callegari E, Liu S, Alder H, Costinean S, Fernandez-Cymering C, Volinia S, Guler G, Morrison CD, Chan KK, Marcucci G, Calin GA, Huebner K, Croce CM (2007) MicroRNA-29 family reverts aberrant methylation in lung cancer by targeting DNA methyltransferases 3A and 3B. Proc Natl Acad Sci U S A 104, 15805-15810

39. Fidler IJ, Brodey RS (1967) The biological behavior of canine mammary neoplasms. J Am Vet Med Assoc 151, 1311-1318

40. Fire A, Xu S, Montgomery MK, Kostas SA, Driver SE, Mello CC (1998) Potent and specific genetic interference by double-stranded RNA in Caenorhabditis elegans. Nature 391, 806-811

41. Fowler EH, Wilson GP, Koestner A (1974) Biologic behavior of canine mammary neoplasms based on a histogenetic classification. Vet Pathol 11, 212-229

42. Frankel LB, Christoffersen NR, Jacobsen A, Lindow M, Krogh A, Lund AH (2007) Programmed cell death 4 (PDCD4) is an important functional target of the microRNA miR-21 in breast cancer cells. J Biol Chem

43. Fu H, Tie Y, Xu C, Zhang Z, Zhu J, Shi Y, Jiang H, Sun Z, Zheng X (2005) Identification of human fetal liver miRNAs by a novel method. FEBS Letters 579, 38493854

44. Gibbs RA, Weinstock GM, Metzker ML, Muzny DM, Sodergren EJ, Scherer S, Scott G, Steffen D, Worley KC, Burch PE, Okwuonu G, Hines S, Lewis L, DeRamo C, Delgado O, Dugan-Rocha S, Miner G, Morgan M, Hawes A, Gill R, Celera, Holt RA, Adams MD, Amanatides PG, Baden-Tillson H, Barnstead M, Chin S, Evans CA, Ferriera S, Fosler C, Glodek A, Gu Z, Jennings D, Kraft CL, Nguyen T, Pfannkoch CM, Sitter C, Sutton GG, Venter JC, Woodage T, Smith D, Lee HM, Gustafson E, Cahill P, Kana A, Doucette-Stamm L, Weinstock K, Fechtel K, Weiss RB, Dunn DM, Green ED, 
Blakesley RW, Bouffard GG, De Jong PJ, Osoegawa K, Zhu B, Marra M, Schein J, Bosdet I, Fjell C, Jones S, Krzywinski M, Mathewson C, Siddiqui A, Wye N, McPherson J, Zhao S, Fraser CM, Shetty J, Shatsman S, Geer K, Chen Y, Abramzon S, Nierman WC, Havlak PH, Chen R, Durbin KJ, Egan A, Ren Y, Song XZ, Li B, Liu Y, Qin X, Cawley S, Cooney AJ, D'Souza LM, Martin K, Wu JQ, Gonzalez-Garay ML, Jackson AR, Kalafus KJ, McLeod MP, Milosavljevic A, Virk D, Volkov A, Wheeler DA, Zhang Z, Bailey JA, Eichler EE, Tuzun E, Birney E, Mongin E, Ureta-Vidal A, Woodwark C, Zdobnov E, Bork P, Suyama M, Torrents D, Alexandersson M, Trask BJ, Young JM, Huang H, Wang H, Xing H, Daniels S, Gietzen D, Schmidt J, Stevens K, Vitt U, Wingrove J, Camara F, Mar Alba M, Abril JF, Guigo R, Smit A, Dubchak I, Rubin EM, Couronne O, Poliakov A, Hubner N, Ganten D, Goesele C, Hummel O, Kreitler T, Lee YA, Monti J, Schulz H, Zimdahl H, Himmelbauer H, Lehrach H, Jacob HJ, Bromberg S, Gullings-Handley J, Jensen-Seaman MI, Kwitek AE, Lazar J, Pasko D, Tonellato PJ, Twigger S, Ponting CP, Duarte JM, Rice S, Goodstadt L, Beatson SA, Emes RD, Winter EE, Webber C, Brandt P, Nyakatura G, Adetobi M, Chiaromonte F, Elnitski L, Eswara P, Hardison RC, Hou M, Kolbe D, Makova K, Miller W, Nekrutenko A, Riemer C, Schwartz S, Taylor J, Yang S, Zhang Y, Lindpaintner K, Andrews TD, Caccamo M, Clamp M, Clarke L, Curwen V, Durbin R, Eyras E, Searle SM, Cooper GM, Batzoglou S, Brudno M, Sidow A, Stone EA, Payseur BA, Bourque G, Lopez-Otin C, Puente XS, Chakrabarti K, Chatterji S, Dewey C, Pachter L, Bray N, Yap VB, Caspi A, Tesler G, Pevzner PA, Haussler D, Roskin KM, Baertsch R, Clawson H, Furey TS, Hinrichs AS, Karolchik D, Kent WJ, Rosenbloom KR, Trumbower H, Weirauch M, Cooper DN, Stenson PD, Ma B, Brent M, Arumugam M, Shteynberg D, Copley RR, Taylor MS, Riethman H, Mudunuri U, Peterson J, Guyer M, Felsenfeld A, Old S, Mockrin S, Collins F (2004) Genome sequence of the Brown Norway rat yields insights into mammalian evolution. Nature 428, 493-521

45. Gilbertson SR, Kurzman ID, Zachrau RE, Hurvitz AI, Black MM (1983) Canine mammary epithelial neoplasms: biologic implications of morphologic characteristics assessed in 232 dogs. Vet Pathol 20, 127-142

46. Griffiths-Jones S, Grocock RJ, Dongen Sv, Bateman A, Enright AJ (2006) miRBase: microRNA sequences, targets and gene nomenclature Nucleic Acids Research 34, D140-144

47. Guyon R, Lorentzen TD, Hitte C, Kim L, Cadieu E, Parker HG, Quignon P, Lowe JK, Renier C, Gelfenbeyn B, Vignaux F, DeFrance HB, Gloux S, Mahairas GG, Andre C, Galibert F, Ostrander EA (2003) A 1-Mb resolution radiation hybrid map of the canine genome. Proc Natl Acad Sci U S A 100, 5296-5301

48. Haga S, Nakayama M, Tatsumi K, Maeda M, Imai S, Umesako S, Yamamoto H, Hilgers J, Sarkar NH (2001) Overexpression of the p53 gene product in canine mammary tumors. Oncol Rep 8, 1215-1219 
49. Hayashita Y, Osada H, Tatematsu Y, Yamada H, Yanagisawa K, Tomida S, Yatabe Y, Kawahara K, Sekido Y, Takahashi T (2005) A Polycistronic MicroRNA Cluster, miR-17-92, Is Overexpressed in Human Lung Caners and Enhances Cell Proliferation. Cancer Research 65, 9628-9632

50. He L, Thomson JM, Hemann MT, Hernando-Monge E, Mu D, Goodson S, Powers S, Cordon-Cardo C, Lowe SW, Hannon GJ, Hammond SM (2005) A microRNA polycistron as a potential human oncogene. Nature 435, 828-833

51. Heller DA, Clifford CA, Goldschmidt MH, Holt DE, Shofer FS, Smith A, Sorenmo KU (2005) Cyclooxygenase-2 expression is associated with histologic tumor type in canine mammary carcinoma. Vet Pathol 42, 776-780

52. Hellmen E, Bergstrom R, Holmberg L, Spangberg IB, Hansson K, Lindgren A (1993) Prognostic factors in canine mammary tumors: a multivariate study of 202 consecutive cases. Vet Pathol 30, 20-27

53. Hershey AE, Kurzman ID, Forrest LJ, Bohling CA, Stonerook M, Placke ME, Imondi AR, Vail DM (1999) Inhalation chemotherapy for macroscopic primary or metastatic lung tumors: proof of principle using dogs with spontaneously occurring tumors as a model. Clin Cancer Res 5, 2653-2659

54. Hossain A, Kuo MT, Saunders GF (2006) Mir-17-5p regulates breast cancer cell proliferation by inhibiting translation of AIB1 mRNA. Mol Cell Biol 26, 8191-8201

55. Houbaviy HB, Dennis L, Jaenisch R, Sharp PA (2005) Characterization of a highly variable eutherian microRNA gene. RNA 11, 1245-1257

56. Hurteau GJ, Carlson JA, Spivack SD, Brock GJ (2007) Overexpression of the microRNA hsa-miR-200c leads to reduced expression of transcription factor 8 and increased expression of E-cadherin. Cancer Res 67, 7972-7976

57. Hwang HW, Mendell JT (2006) MicroRNAs in cell proliferation, cell death, and tumorigenesis. Br J Cancer 94, 776-780

58. Illera JC, Perez-Alenza MD, Nieto A, Jimenez MA, Silvan G, Dunner S, Pena L (2006) Steroids and receptors in canine mammary cancer. Steroids 71, 541-548

59. Iorio MV, Ferracin M, Liu CG, Veronese A, Spizzo R, Sabbioni S, Magri E, Pedriali M, Fabbri M, Campiglio M, Menard S, Palazzo JP, Rosenberg A, Musiani P, Volinia S, Nenci I, Calin GA, Querzoli P, Negrini M, Croce CM (2005) MicroRNA gene expression deregulation in human breast cancer. Cancer Res 65, 7065-7070 
60. Itoh T, Uchida K, Ishikawa K, Kushima K, Kushima E, Tamada H, Moritake T, Nakao H, Shii H (2005) Clinicopathological survey of 101 canine mammary gland tumors: differences between small-breed dogs and others. J Vet Med Sci 67, 345-347

61. Iwata H (2007) Perspective of trastuzumab treatment. Breast Cancer 14, 150-155

62. Jiang J, Lee EJ, Gusev Y, Schmittgen TD (2005) Real-time expression profiling of microRNA precursors in human cancer cell lines. Nucleic Acids Res 33, 5394-5403

63. Johnson CD, Esquela-Kerscher A, Stefani G, Byrom M, Kelnar K, Ovcharenko D, Wilson M, Wang X, Shelton J, Shingara J, Chin L, Brown D, Slack FJ (2007) The let-7 microRNA represses cell proliferation pathways in human cells. Cancer Res 67, 7713-7722

64. Johnson SM, Grosshans H, Shingara J, Byrom M, Jarvis R, Cheng A, Labourier E, Reinert KL, Brown D, Slack FJ (2005) RAS is regulated by the let-7 microRNA family. Cell 120, 635-647

65. Karayannopoulou M, Kaldrymidou E, Constantinidis TC, Dessiris A (2001) Adjuvant post-operative chemotherapy in bitches with mammary cancer. J Vet Med A Physiol Pathol Clin Med 48, 85-96

66. Kiriakidou M, Nelson PT, Kouranov A, Fitziev P, Bouyioukos C, Mourelatos Z, Hatzigeorgiou A (2004) A combined computational-experimental approach predicts human microRNA targets. Genes Dev 18, 1165-1178

67. Kirkness EF, Bafna V, Halpern AL, Levy S, Remington K, Rusch DB, Delcher AL, Pop M, Wang W, Fraser CM, Venter JC (2003) The dog genome: survey sequencing and comparative analysis. Science 301, 1898-1903

68. Kovalchuk O, Tryndyak VP, Montgomery B, Boyko A, Kutanzi K, Zemp F, Warbritton AR, Latendresse JR, Kovalchuk I, Beland FA, Pogribny IP (2007) Estrogeninduced rat breast carcinogenesis is characterized by alterations in DNA methylation, histone modifications and aberrant microRNA expression. Cell Cycle 6, 2010-2018

69. Kumaraguruparan R, Prathiba D, Nagini S (2006) Of humans and canines: Immunohistochemical analysis of PCNA, Bcl-2, p53, cytokeratin and ER in mammary tumours. Res Vet Sci 81, 218-224

70. Kurzman ID, Gilbertson SR (1986) Prognostic factors in canine mammary tumors. Semin Vet Med Surg (Small Anim) 1, 25-32

71. Lacroix M, Toillon RA, Leclercq G (2006) p53 and breast cancer, an update. Endocr Relat Cancer 13, 293-325 
72. Lagos-Quintana M, Rauhut R, Lendeckel W, Tuschl T (2001) Identification of novel genes coding for small expressed RNAs. Science 294, 853-858

73. Lagos-Quintana M, Rauhut R, Yalcin A, Meyer J, Lendeckel W, Tuschl T (2002) Identification of tissue-specific microRNAs from mouse. Current Biology 12, 735-739

74. Lana SE, Rutteman GR, Withrow SJ (2007) Tumors of the mammary gland. In Withrow \& MacEwen's Small Animal Clinical Oncology, S.J. Withrow, D.M. Vail, eds. (St. Louis: Saunders Elsevier), pp 619-636

75. Laumbacher B, Fellerhoff B, Herzberger B, Wank R (2006) Do dogs harbour risk factors for human breast cancer? Med Hypotheses 67, 21-26

76. Lecellier CH, Dunoyer P, Arar K, Lehmann-Che J, Eyquem S, Himber C, Saib A, Voinnet O (2005) A cellular microRNA mediates antiviral defense in human cells. Science 308, 557-560

77. Lee RC, Feinbaum RL, Ambros V (1993) The C. elegans Heterochronic Gene lin-4 Encodes Small RNAs with Antisense Complementarity to lin-14. Cell 75, 843-854

78. Lee YS, Kim HK, Chung S, Kim KS, Dutta A (2005) Depletion of human microRNA miR-125b reveals that it is critical for the proliferation of differentiated cells but not for the down-regulation of putative targets during differentiation. J Biol Chem 280, 16635-16641

79. Lehmann U, Hasemeier B, Christgen M, Muller M, Romermann D, Langer F, Kreipe H (2007) Epigenetic inactivation of microRNA gene hsa-mir-9-1 in human breast cancer. J Pathol

80. Lindblad-Toh K, Wade CM, Mikkelsen TS, Karlsson EK, Jaffe DB, Kamal M, Clamp M, Chang JL, Kulbokas EJ, 3rd, Zody MC, Mauceli E, Xie X, Breen M, Wayne RK, Ostrander EA, Ponting CP, Galibert F, Smith DR, DeJong PJ, Kirkness E, Alvarez P, Biagi T, Brockman W, Butler J, Chin CW, Cook A, Cuff J, Daly MJ, DeCaprio D, Gnerre S, Grabherr M, Kellis M, Kleber M, Bardeleben C, Goodstadt L, Heger A, Hitte C, Kim L, Koepfli KP, Parker HG, Pollinger JP, Searle SM, Sutter NB, Thomas R, Webber C, Baldwin J, Abebe A, Abouelleil A, Aftuck L, Ait-Zahra M, Aldredge T, Allen N, An P, Anderson S, Antoine C, Arachchi H, Aslam A, Ayotte L, Bachantsang P, Barry A, Bayul T, Benamara M, Berlin A, Bessette D, Blitshteyn B, Bloom T, Blye J, Boguslavskiy L, Bonnet C, Boukhgalter B, Brown A, Cahill P, Calixte N, Camarata J, Cheshatsang Y, Chu J, Citroen M, Collymore A, Cooke P, Dawoe T, Daza R, Decktor K, DeGray S, Dhargay N, Dooley K, Dorje P, Dorjee K, Dorris L, Duffey N, Dupes A, Egbiremolen O, Elong R, Falk J, Farina A, Faro S, Ferguson D, Ferreira P, Fisher S, FitzGerald M, Foley K, Foley C, Franke A, Friedrich D, Gage D, Garber M, Gearin G, Giannoukos G, Goode T, Goyette A, Graham J, Grandbois E, Gyaltsen K, Hafez N, 
Hagopian D, Hagos B, Hall J, Healy C, Hegarty R, Honan T, Horn A, Houde N, Hughes L, Hunnicutt L, Husby M, Jester B, Jones C, Kamat A, Kanga B, Kells C, Khazanovich D, Kieu AC, Kisner P, Kumar M, Lance K, Landers T, Lara M, Lee W, Leger JP, Lennon N, Leuper L, LeVine S, Liu J, Liu X, Lokyitsang Y, Lokyitsang T, Lui A, Macdonald J, Major J, Marabella R, Maru K, Matthews C, McDonough S, Mehta T, Meldrim J, Melnikov A, Meneus L, Mihalev A, Mihova T, Miller K, Mittelman R, Mlenga V, Mulrain L, Munson G, Navidi A, Naylor J, Nguyen T, Nguyen N, Nguyen C, Nicol R, Norbu N, Norbu C, Novod N, Nyima T, Olandt P, O'Neill B, O'Neill K, Osman S, Oyono L, Patti C, Perrin D, Phunkhang P, Pierre F, Priest M, Rachupka A, Raghuraman S, Rameau R, Ray V, Raymond C, Rege F, Rise C, Rogers J, Rogov P, Sahalie J, Settipalli S, Sharpe T, Shea T, Sheehan M, Sherpa N, Shi J, Shih D, Sloan J, Smith C, Sparrow T, Stalker J, Stange-Thomann N, Stavropoulos S, Stone C, Stone S, Sykes S, Tchuinga P, Tenzing P, Tesfaye S, Thoulutsang D, Thoulutsang Y, Topham K, Topping I, Tsamla T, Vassiliev H, Venkataraman V, Vo A, Wangchuk T, Wangdi T, Weiand M, Wilkinson J, Wilson A, Yadav S, Yang S, Yang X, Young G, Yu Q, Zainoun J, Zembek L, Zimmer A, Lander ES (2005) Genome sequence, comparative analysis and haplotype structure of the domestic dog. Nature 438, 803-819

81. Lu J, Getz G, Miska EA, Alvarez-Saavedra E, Lamb J, Peck D, Sweet-Cordero A, Ebert BL, Mak RH, Ferrando AA, Downing JR, Jacks T, Horvitz HR, Golub TR (2005) MicroRNA expression profiles classify human cancers. Nature 435, 834-838

82. Ma L, Teruya-Feldstein J, Weinberg RA (2007) Tumour invasion and metastasis initiated by microRNA-10b in breast cancer. Nature 449, 682-688

83. MacEwen EG, Harvey HJ, Patnaik AK, Mooney S, Hayes A, Kurzman I, Hardy WD, Jr. (1985) Evaluation of effects of levamisole and surgery on canine mammary cancer. J Biol Response Mod 4, 418-426

84. MacEwen EG, Patnaik AK, Harvey HJ, Panko WB (1982) Estrogen receptors in canine mammary tumors. Cancer Res 42, 2255-2259

85. Mattie MD, Benz CC, Bowers J, Sensinger K, Wong L, Scott GK, Fedele V, Ginzinger D, Getts R, Haqq C (2006) Optimized high-throughput microRNA expression profiling provides novel biomarker assessment of clinical prostate and breast cancer biopsies. Mol Cancer 5, 24

86. Meng F, Henson R, Wehbe-Janek H, Ghoshal K, Jacob ST, Patel T (2007) MicroRNA-21 regulates expression of the PTEN tumor suppressor gene in human hepatocellular cancer. Gastroenterology 133, 647-658

87. Mertens-Talcott SU, Chintharlapalli S, Li X, Safe S (2007) The oncogenic microRNA-27a targets genes that regulate specificity protein transcription factors and the G2-M checkpoint in MDA-MB-231 breast cancer cells. Cancer Res 67, 11001-11011 
88. Michael MZ, SM OC, van Holst Pellekaan NG, Young GP, James RJ (2003) Reduced accumulation of specific microRNAs in colorectal neoplasia. Mol Cancer Res $1,882-891$

89. Miki Y, Swensen J, Shattuck-Eidens D, Futreal PA, Harshman K, Tavtigian S, Liu Q, Cochran C, Bennett LM, Ding W, et al. (1994) A strong candidate for the breast and ovarian cancer susceptibility gene BRCA1. Science 266, 66-71

90. Millanta F, Calandrella M, Bari G, Niccolini M, Vannozzi I, Poli A (2005) Comparison of steroid receptor expression in normal, dysplastic, and neoplastic canine and feline mammary tissues. Res Vet Sci 79, 225-232

91. Misdorp W, den Herder BA (1966) Bone metastasis in mammary cancer. A report of 10 cases in the female dog and some comparison with human cases. $\mathrm{Br} \mathbf{J}$ Cancer 20, 496-503

92. Miyoshi N, Tateyama S, Ogawa K, Yamaguchi R, Kuroda H, Yasuda N, Shimizu $\mathrm{T}$ (1991) Abnormal structure of the canine oncogene, related to the human c-yes-1 oncogene, in canine mammary tumor tissue. Am J Vet Res 52, 2046-2049

93. Mol JA, Selman PJ, Sprang EP, van Neck JW, Oosterlaken-Dijksterhuis MA (1997) The role of progestins, insulin-like growth factor (IGF) and IGF-binding proteins in the normal and neoplastic mammary gland of the bitch: a review. J Reprod Fertil Suppl 51, 339-344

94. Morris JS, Dobson JM, Bostock DE (1993) Use of tamoxifen in the control of canine mammary neoplasia. Vet Rec 133, 539-542

95. Morris JS, Dobson JM, Bostock DE, O'Farrell E (1998) Effect of ovariohysterectomy in bitches with mammary neoplasms. Vet Rec 142, 656-658

96. Mott JL, Kobayashi S, Bronk SF, Gores GJ (2007) mir-29 regulates Mcl-1 protein expression and apoptosis. Oncogene 26, 6133-6140

97. Moulton JE, Rosenblatt LS, Goldman M (1986) Mammary tumors in a colony of beagle dogs. Vet Pathol 23, 741-749

98. Murphy WJ, Eizirik E, O'Brien SJ, Madsen O, Scally M, Douady CJ, Teeling E, Ryder OA, Stanhope MJ, de Jong WW, Springer MS (2001) Resolution of the early placental mammal radiation using Bayesian phylogenetics. Science 294, 2348-2351

99. Neve RM, Chin K, Fridlyand J, Yeh J, Baehner FL, Fevr T, Clark L, Bayani N, Coppe JP, Tong F, Speed T, Spellman PT, DeVries S, Lapuk A, Wang NJ, Kuo WL, 
Stilwell JL, Pinkel D, Albertson DG, Waldman FM, McCormick F, Dickson RB, Johnson MD, Lippman M, Ethier S, Gazdar A, Gray JW (2006) A collection of breast cancer cell lines for the study of functionally distinct cancer subtypes. Cancer Cell 10, $515-527$

100. Nieto A, Pena L, Perez-Alenza MD, Sanchez MA, Flores JM, Castano M (2000) Immunohistologic detection of estrogen receptor alpha in canine mammary tumors: clinical and pathologic associations and prognostic significance. Vet Pathol 37, 239-247

101. Nieto A, Perez-Alenza MD, Del Castillo N, Tabanera E, Castano M, Pena L (2003) BRCA1 expression in canine mammary dysplasias and tumours: relationship with prognostic variables. J Comp Pathol 128, 260-268

102. O'Donnell KA, Wentzel EA, Zeller KI, Dang CV, Mendell JT (2005) c-Mycregulated microRNAs modulate E2F1 expression. Nature 435, 839-843

103. Ostrander EA, Galibert F, Patterson DF (2000) Canine genetics comes of age. Trends Genet 16, 117-124

104. Parker HG, Ostrander EA (2005) Canine genomics and genetics: running with the pack. PLoS Genet 1, e58

105. Parodi AL, Misdorp W, Mialot JP, Mialot M, Hart AA, Hurtrel M, Salomon JC (1983) Intratumoral BCG and Corynebacterium parvum therapy of canine mammary tumours before radical mastectomy. Cancer Immunol Immunother 15, 172-177

106. Pasquinelli AE, Reinhart BJ, Slack F, Martindale MQ, Kuroda MI, Maller B, Hayward DC, Ball EE, Degnan B, Muller P, Spring J, Srinivasan A, Fishman M, Finnerty J, Corbo J, Levine M, Leahy P, Davidson E, Ruvkun G (2000) Conservation of the sequence and temporal expression of let-7 heterochronic regulatory RNA. Nature 408, 86-89

107. Pekarsky Y, Santanam U, Cimmino A, Palamarchuk A, Efanov A, Maximov V, Volinia S, Alder H, Liu CG, Rassenti L, Calin GA, Hagan JP, Kipps T, Croce CM (2006) Tcl1 expression in chronic lymphocytic leukemia is regulated by miR-29 and miR-181. Cancer Res 66, 11590-11593

108. Pena L, Perez-Alenza MD, Rodriguez-Bertos A, Nieto A (2003a) Canine inflammatory mammary carcinoma: histopathology, immunohistochemistry and clinical implications of 21 cases. Breast Cancer Res Treat 78, 141-148

109. Pena L, Silvan G, Perez-Alenza MD, Nieto A, Illera JC (2003b) Steroid hormone profile of canine inflammatory mammary carcinoma: a preliminary study. J Steroid Biochem Mol Biol 84, 211-216 
110. Perez Alenza D, Rutteman GR, Pena L, Beynen AC, Cuesta P (1998) Relation between habitual diet and canine mammary tumors in a case-control study. $\mathrm{J}$ Vet Intern Med 12, 132-139

111. Perez Alenza MD, Tabanera E, Pena L (2001) Inflammatory mammary carcinoma in dogs: 33 cases (1995-1999). J Am Vet Med Assoc 219, 1110-1114

112. Queiroga FL, Perez-Alenza MD, Silvan G, Pena L, Lopes C, Illera JC (2005a) Cox-2 levels in canine mammary tumors, including inflammatory mammary carcinoma: clinicopathological features and prognostic significance. Anticancer Res 25, 4269-4275

113. Queiroga FL, Perez-Alenza MD, Silvan G, Pena L, Lopes C, Illera JC (2005b) Role of steroid hormones and prolactin in canine mammary cancer. J Steroid Biochem Mol Biol 94, 181-187

114. Reinhart BJ, Slack FJ, Basson M, Pasquinelli AE, Bettinger JC, Rougvie AE, Horvitz HR, Ruvkun G (2000) The 21-nucleotide let-7 RNA regulates developmental timing in Caenorhabditis elegans. Nature 403, 901-906

115. Roldo C, Missiaglia E, Hagan JP, Falconi M, Capelli P, Bersani S, Calin GA, Volinia S, Liu CG, Scarpa A, Croce CM (2006) MicroRNA expression abnormalities in pancreatic endocrine and acinar tumors are associated with distinctive pathologic features and clinical behavior. J Clin Oncol 24, 4677-4684

116. Romanucci M, Marinelli A, Sarli G, Della Salda L (2006) Heat shock protein expression in canine malignant mammary tumours. BMC Cancer 6, 171

117. Rungsipipat A, Tateyama S, Yamaguchi R, Uchida K, Miyoshi N, Hayashi T (1999a) Immunohistochemical analysis of c-yes and c-erbB-2 oncogene products and p53 tumor suppressor protein in canine mammary tumors. J Vet Med Sci 61, 27-32

118. Rungsipipat A, Tateyama S, Yamaguchi R, Uchida K, Murakami Y, Miyoshi N, Hayashi T (1999b) Amplification of the c-yes oncogene in canine mammary tumors. J Vet Med Sci 61, 185-189

119. Rutteman GR, Cornelisse CJ, Dijkshoorn NJ, Poortman J, Misdorp W (1988a) Flow cytometric analysis of DNA ploidy in canine mammary tumors. Cancer Res 48, 3411-3417

120. Rutteman GR, Misdorp W, Blankenstein MA, van den Brom WE (1988b) Oestrogen (ER) and progestin receptors (PR) in mammary tissue of the female dog: different receptor profile in non-malignant and malignant states. Br J Cancer 58, 594599 
121. Sartin EA, Barnes S, Kwapien RP, Wolfe LG (1992) Estrogen and progesterone receptor status of mammary carcinomas and correlation with clinical outcome in dogs. Am J Vet Res 53, 2196-2200

122. Sartin EA, Barnes S, Toivio-Kinnucan M, Wright JC, Wolfe LG (1993) Heterogenic properties of clonal cell lines derived from canine mammary carcinomas and sensitivity to tamoxifen and doxorubicin. Anticancer Res 13, 229-236

123. Sawera M, Gorodkin J, Cirera S, Fredholm M (2005) Mapping and expression studies of the mir17-92 cluster on pig Chromosome 11. Mammalian Genome 16, 594598

124. Schneider R, Dorn CR, Taylor DO (1969) Factors influencing canine mammary cancer development and postsurgical survival. J Natl Cancer Inst 43, 1249-1261

125. Scott GK, Mattie MD, Berger CE, Benz SC, Benz CC (2006) Rapid alteration of microRNA levels by histone deacetylase inhibition. Cancer Res 66, 1277-1281

126. Sempere LF, Freemantle S, Pitha-Rowe I, Moss E, Dmitrovsky E, Ambros V (2004) Expression profiling of mammalian microRNAs uncovers a subset of brainexpressed microRNAs with possible roles in murine and human neuronal differentiation. Genome Biology 5, R13

127. Si ML, Zhu S, Wu H, Lu Z, Wu F, Mo YY (2007) miR-21-mediated tumor growth. Oncogene 26, 2799-2803

128. Silveri L, Tilly G, Vilotte JL, Le Provost F (2006) MicroRNA involvement in mammary gland development and breast cancer. Reprod Nutr Dev 46, 549-556

129. Simon D, Schoenrock D, Baumgartner W, Nolte I (2006) Postoperative adjuvant treatment of invasive malignant mammary gland tumors in dogs with doxorubicin and docetaxel. J Vet Intern Med 20, 1184-1190

130. Sonnenschein EG, Glickman LT, Goldschmidt MH, McKee LJ (1991) Body conformation, diet, and risk of breast cancer in pet dogs: a case-control study. Am J Epidemiol 133, 694-703

131. Sorenmo K (2003) Canine mammary gland tumors. Vet Clin North Am Small Anim Pract 33, 573-596

132. Sorenmo KU, Shofer FS, Goldschmidt MH (2000) Effect of spaying and timing of spaying on survival of dogs with mammary carcinoma. J Vet Intern Med 14, 266-270 
133. Springer MS, Murphy WJ, Eizirik E, O'Brien SJ (2003) Placental mammal diversification and the Cretaceous-Tertiary boundary. Proc Natl Acad Sci U S A 100, 1056-1061

134. Stovring M, Moe L, Glattre E (1997) A population-based case-control study of canine mammary tumours and clinical use of medroxyprogesterone acetate. APMIS 105, 590-596

135. Tanzer A, Stadler PF (2004) Molecular Evolution of a MicroRNA Cluster. Journal of Molecular Biology 339, 327-335

136. Thermann R, Hentze MW (2007) Drosophila miR2 induces pseudo-polysomes and inhibits translation initiation. Nature

137. Thomson JM, Newman M, Parker JS, Morin-Kensicki EM, Wright T, Hammond SM (2006) Extensive post-transcriptional regulation of microRNAs and its implications for cancer. Genes \& Development 20, 2202-2207

138. Tsuchiya Y, Nakajima M, Takagi S, Taniya T, Yokoi T (2006) MicroRNA regulates the expression of human cytochrome P450 1B1. Cancer Res 66, 9090-9098

139. Van Leeuwen IS, Hellmen E, Cornelisse CJ, Van den Burgh B, Rutteman GR (1996) P53 mutations in mammary tumor cell lines and corresponding tumor tissues in the dog. Anticancer Res 16, 3737-3744

140. Vargo-Gogola T, Rosen JM (2007) Modelling breast cancer: one size does not fit all. Nat Rev Cancer 7, 659-672

141. Veldhoen N, Watterson J, Brash M, Milner J (1999) Identification of tumourassociated and germ line p53 mutations in canine mammary cancer. Br J Cancer 81, 409415

142. Volina S, Calin GA, Liu C-G, Ambs S, Cimmino A, Petrocca F, Visone R, Iorio M, Roldo C, Ferracin M, Prueitt RL, Yanaihara N, Lanza G, Scarpa A, Vecchione A, Negrini M, Harris CC, Croce CM (2006) A microRNA expression signature of human solid tumors defines cancer gene targets. PNAS 103, 2257-2261

143. Volinia S, Calin GA, Liu CG, Ambs S, Cimmino A, Petrocca F, Visone R, Iorio M, Roldo C, Ferracin M, Prueitt RL, Yanaihara N, Lanza G, Scarpa A, Vecchione A, Negrini M, Harris CC, Croce CM (2006) A microRNA expression signature of human solid tumors defines cancer gene targets. Proc Natl Acad Sci U S A 103, 2257-2261 
144. Walboomers JM, Jacobs MV, Manos MM, Bosch FX, Kummer JA, Shah KV, Snijders PJ, Peto J, Meijer CJ, Munoz N (1999) Human papillomavirus is a necessary cause of invasive cervical cancer worldwide. J Pathol 189, 12-19

145. Waterston RH, Lindblad-Toh K, Birney E, Rogers J, Abril JF, Agarwal P, Agarwala R, Ainscough R, Alexandersson M, An P, Antonarakis SE, Attwood J, Baertsch R, Bailey J, Barlow K, Beck S, Berry E, Birren B, Bloom T, Bork P, Botcherby M, Bray N, Brent MR, Brown DG, Brown SD, Bult C, Burton J, Butler J, Campbell RD, Carninci P, Cawley S, Chiaromonte F, Chinwalla AT, Church DM, Clamp M, Clee C, Collins FS, Cook LL, Copley RR, Coulson A, Couronne O, Cuff J, Curwen V, Cutts T, Daly M, David R, Davies J, Delehaunty KD, Deri J, Dermitzakis ET, Dewey C, Dickens NJ, Diekhans M, Dodge S, Dubchak I, Dunn DM, Eddy SR, Elnitski L, Emes RD, Eswara P, Eyras E, Felsenfeld A, Fewell GA, Flicek P, Foley K, Frankel WN, Fulton LA, Fulton RS, Furey TS, Gage D, Gibbs RA, Glusman G, Gnerre S, Goldman N, Goodstadt L, Grafham D, Graves TA, Green ED, Gregory S, Guigo R, Guyer M, Hardison RC, Haussler D, Hayashizaki Y, Hillier LW, Hinrichs A, Hlavina W, Holzer T, Hsu F, Hua A, Hubbard T, Hunt A, Jackson I, Jaffe DB, Johnson LS, Jones M, Jones TA, Joy A, Kamal M, Karlsson EK, Karolchik D, Kasprzyk A, Kawai J, Keibler E, Kells C, Kent WJ, Kirby A, Kolbe DL, Korf I, Kucherlapati RS, Kulbokas EJ, Kulp D, Landers T, Leger JP, Leonard S, Letunic I, Levine R, Li J, Li M, Lloyd C, Lucas S, Ma B, Maglott DR, Mardis ER, Matthews L, Mauceli E, Mayer JH, McCarthy M, McCombie WR, McLaren S, McLay K, McPherson JD, Meldrim J, Meredith B, Mesirov JP, Miller W, Miner TL, Mongin E, Montgomery KT, Morgan M, Mott R, Mullikin JC, Muzny DM, Nash WE, Nelson JO, Nhan MN, Nicol R, Ning Z, Nusbaum C, O'Connor MJ, Okazaki Y, Oliver K, Overton-Larty E, Pachter L, Parra G, Pepin KH, Peterson J, Pevzner P, Plumb R, Pohl CS, Poliakov A, Ponce TC, Ponting CP, Potter S, Quail M, Reymond A, Roe BA, Roskin KM, Rubin EM, Rust AG, Santos R, Sapojnikov V, Schultz B, Schultz J, Schwartz MS, Schwartz S, Scott C, Seaman S, Searle S, Sharpe T, Sheridan A, Shownkeen R, Sims S, Singer JB, Slater G, Smit A, Smith DR, Spencer B, Stabenau A, Stange-Thomann N, Sugnet C, Suyama M, Tesler G, Thompson J, Torrents D, Trevaskis E, Tromp J, Ucla C, Ureta-Vidal A, Vinson JP, Von Niederhausern AC, Wade CM, Wall M, Weber RJ, Weiss RB, Wendl MC, West AP, Wetterstrand K, Wheeler R, Whelan S, Wierzbowski J, Willey D, Williams S, Wilson RK, Winter E, Worley KC, Wyman D, Yang S, Yang SP, Zdobnov EM, Zody MC, Lander ES (2002) Initial sequencing and comparative analysis of the mouse genome. Nature 420, 520-562

146. Wightman B, Ha I, Ruvkun G (1993) Posttranscriptional regulation of the heterochronic gene lin-14 by lin-4 mediates temporal pattern formation in C. elegans. Cell 75, 855-862

147. Wijnhoven BP, Michael MZ, Watson DI (2007) MicroRNAs and cancer. Br J Surg 94, 23-30 
148. Wildman DE, Uddin M, Opazo JC, Liu G, Lefort V, Guindon S, Gascuel O, Grossman LI, Romero R, Goodman M (2007) Genomics, biogeography, and the diversification of placental mammals. Proc Natl Acad Sci U S A 104, 14395-14400

149. Wu L, Belasco JG (2005) Micro-RNA regulation of the mammalian lin-28 gene during neuronal differentiation of embryonal carcinoma cells. Mol Cell Biol 25, 91989208

150. Xie X, Lu J, Kulbokas EJ, Golub TR, Mootha V, Lindblad-Toh K, Lander ES, Kellis M (2005) Systematic discovery of regulatory motifs in human promoters and 3' UTRs by comparison of several mammals. Nature 434, 338-345

151. Yamagami T, Kobayashi T, Takahashi K, Sugiyama M (1996) Influence of ovariectomy at the time of mastectomy on the prognosis for canine malignant mammary tumours. J Small Anim Pract 37, 462-464

152. Zhang B, Pan X, Cobb GP, Anderson TA (2007) microRNAs as oncogenes and tumor suppressors. Dev Biol 302, 1-12

153. Zhang L, Huang J, Yang N, Greshock J, Megraw MS, Giannakakis A, Liang S, Naylor TL, Barchetti A, Ward MR, Yao G, Medina A, O'Brien-Jenkins A, Katsaros D, Hatzigeorgiou A, Gimotty PA, Weber BL, Coukos G (2006) microRNAs exhibit high frequency genomic alterations in human cancer. Proc Natl Acad Sci U S A 103, 91369141

154. Zhu S, Si ML, Wu H, Mo YY (2007) MicroRNA-21 targets the tumor suppressor gene tropomyosin 1 (TPM1). J Biol Chem 282, 14328-14336 
VITA

Name: $\quad$ René Michelle Boggs

Address: $\quad$ TAMU-CVM

Department of Veterinary Integrative Biosciences

MS 4458

College Station, Texas 77843-4458

Email Address: rmboggsphd@yahoo.com

Education: $\quad$ B.S., Biomedical Science, Texas A\&M University, 2004

Ph.D., Veterinary Microbiology, Texas A\&M University, 2008

Honors and Awards:

Received the Award for Best Graduate Student Poster Presentation at the Annual Gulf Coast Society of Toxicology Meeting, 2007

Received the Award for Best Graduate Student Oral Presentation at the $34^{\text {th }}$ Annual Texas Genetics Society Meeting, 2007

Placed $1^{\text {st }}$ in TAMU's Student Research Competition for the Genetics--Oral Presentation

Category \& Received the Outstanding Accomplishment in Interdisciplinary

Research Award, 2007

Nominated for The Chancellor's List ${ }^{\circledR}, 2005-2006$ Ed.

San Antonio Aggie Mom's Club Scholarship, 2005-2006

Graduated Cum Laude with University Foundation Honors from TAMU, 2004

Texas A\&M University's President Endowed Scholarship, 2000-2004

State of Texas Valedictorian Scholarship for Freshman Tuition, 2000-2001

Publications:

Boggs RM, Moody JA, Long CR, Tsai KL, Murphy KE (2007) Identification, amplification and characterization of miR-17-92 from canine tissue. Gene 404, 12: $25-30$.

Boggs RM, Wright ZM, Stickney MR, Porter WW, Murphy KE (2007) MicroRNA expression in canine mammary cancer. Mammalian Genome (in review).

Funded Grants:

Boggs RM and Tsai KL (2007) MicroRNA expression in the canine genome. Canine Health Foundation. 